\title{
Insights into the genus Diaporthe: phylogenetic species delimitation in the $D$. eres species complex
}

\author{
Dhanushka Udayanga • Lisa A. Castlebury • \\ Amy Y. Rossman • Ekachai Chukeatirote • \\ Kevin D. Hyde
}

Received: 12 June 2014 / Accepted: 15 July 2014 /Published online: 8 August 2014

(C) The Author(s) 2014. This article is published with open access at Springerlink.com

\begin{abstract}
The genus Diaporthe comprises pathogenic, endophytic and saprobic species with both temperate and tropical distributions. Cryptic diversification, phenotypic plasticity and extensive host associations have long complicated accurate identifications of species in this genus. The delimitation of the generic type species Diaporthe eres has been uncertain due to the lack of ex-type cultures. Species limits of $D$. eres and closely related species were evaluated using molecular phylogenetic analysis of eight genes including nuclear ribosomal internal transcribed spacer (ITS), partial sequences of actin
\end{abstract}

Electronic supplementary material The online version of this article (doi:10.1007/s13225-014-0297-2) contains supplementary material, which is available to authorized users.

Mention of trade names or commercial products in this publication is solely for the purpose of providing specific information and does not imply recommendation or endorsement by the USDA. USDA is an equal opportunity provider and employer.

D. Udayanga $\cdot$ K. D. Hyde $(\triangle)$

Key Laboratory for Plant Diversity and Biogeography of East Asia, Kunming Institute of Botany, Chinese Academy of Sciences,

Kunming 650201, People's Republic of China

e-mail: kdhyde3@gmail.com

D. Udayanga $\cdot$ K. D. Hyde

World Agroforestry Centre, East and Central Asia, Kunming 650201, China

D. Udayanga $\cdot$ E. Chukeatirote $\cdot$ K. D. Hyde

Institute of Excellence in Fungal Research, Mae Fah Luang

University, Chiang Rai 57100, Thailand

D. Udayanga $\cdot$ E. Chukeatirote $\cdot$ K. D. Hyde

School of Science, Mae Fah Luang University, Chiang Rai 57100,

Thailand

D. Udayanga $\cdot$ L. A. Castlebury $\cdot$ A. Y. Rossman

Systematic Mycology and Microbiology Laboratory, United States

Department of Agriculture- Agricultural Research Service,

Beltsville, MD 20705, USA
(ACT), DNA-lyase (Apn2), translation elongation factor 1- $\alpha$ (EF1- $\alpha$ ), beta-tubulin (TUB), calmodulin (CAL), 60s ribosomal protein L37 (FG1093) and histone-3 (HIS). The occurrence of sequence heterogeneity of ITS within D. eres is observed, which complicates the analysis and may lead to overestimation of the species diversity. The strict criteria of Genealogical Concordance Phylogenetic Species Recognition (GCPSR) were applied to resolve species boundaries based on individual and combined analyses of other seven genes except the ITS. We accept nine distinct phylogenetic species including Diaporthe alleghaniensis, D. alnea, D. bicincta, D. celastrina, D. eres, $D$. helicis, D. neilliae, D. pulla and D. vaccinii. Epitypes are designated for $D$. alnea, D. bicincta, D. celastrina, D. eres, $D$. helicis and D. pulla. Modern descriptions and illustrations are provided for these species. Newly designed primers are introduced to amplify and sequence the Apn2 (DNA- lyase) gene in Diaporthe. Based on phylogenetic informativeness profiles, EF1- $\alpha$, Apn2 and HIS genes are recognised as the best markers for defining species in the $D$. eres complex.

Keywords Diaporthaceae - DNA-lyase - Epitypification . Gene discordance $\cdot$ Generic type $\cdot$ Molecular phylogeny $\cdot$ New primers $\cdot$ Phylogenetic informativeness $\cdot$ Speciation

\section{Introduction}

In the last two decades much progress has been made in the ability to define fungal species through the use of molecular data (Hibbett and Taylor 2013; Hyde et al. 2013). Circumscribing species within cryptic species complexes that have complicated life histories is essential for determining patterns of speciation and potential hyperdiversity within a genus (Bickford et al. 2007; Silva et al. 2012a; Fekete et al. 2012; O’Donnell et al. 2013). Genealogical Concordance Phylogenetic Species Recognition (GCPSR) as an approach 
for defining fungal species was proposed by Taylor et al. (2000), based on Avise and Ball's (1990) genealogical concordance species concept requiring the analysis of several unlinked genes. This approach is often used as an alternative to morphological and biological species recognition (Dettman et al. 2003a). However, there have been relatively a few evaluations of the utility of genes to delineate closely related species in genera with broad host ranges and wide geographic distributions (Giraud et al. 2008; Dupis et al. 2012; Groenewald et al. 2013; Wikee et al. 2013; Salgado-Salazar et al. 2013).

The principles of GCPSR are based on the assumption that recombination within a lineage is likely to be the reason for conflict within gene trees, with the transition from conflict to congruence representing the species boundaries (Taylor et al. 2000). Selecting multiple genes with strong phylogenetic signals, the absence of significant incongruence and the application of standard criteria to determine the species boundaries are important factors in the best practices of resolving species complexes (O’Donnell et al. 2000; Bischoff et al. 2009; Watanabe et al. 2011; Salichos and Rokas 2013; Damm et al. 2013; Quaedvlieg et al. 2014). Dettman et al. (2003a) further upgraded the operational criteria of GCPSR with the implementation of a two-step process to resolve complex species level phylogenies in fungi. Independent evolutionary lineages are recognised by genealogical concordance and nondiscordance, and subsequently these lineages are subjected to the ranking based on genetic differentiation and exhaustive subdivision process to determine the species limits (Dettman et al. 2003a, b). These methods have been implemented in species complexes including the model ascomycete Neurospora (Dettman et al. 2003b, 2006) and some important plant pathogenic fungal genera (O’Donnell et al. 2004; Taylor et al. 2006; Cai et al. 2011; Laurence et al. 2014). The genus Diaporthe comprises pathogenic, endophytic and saprobic species with both temperate and tropical geographic distributions (Rehner and Uecker 1994; Rossman et al. 2007; Udayanga et al. 2011; Huang et al. 2013). Species recognition criteria in Diaporthe have evolved from morphology and host associations (Wehmeyer 1933) to the recent use of phylogenetic species recognition (Castlebury et al. 2003; Santos and Phillips 2009; Santos et al. 2011; Udayanga et al. 2012a, b; Gomes et al. 2013; Tan et al. 2013).

Diaporthe eres Nitschke, the type species of the genus, was originally described by Nitschke (1870), from Ulmus sp. collected in Germany. Wehmeyer (1933) listed a number of synonyms under $D$. eres with approximately 70 host associations belonging to a wide range of plant families based on morphological characters. Despite Wehmeyer's (1933) broad concept of $D$. eres, a comprehensive study of this species has not been attempted (Udayanga et al. 2011; Gomes et al. 2013). Few of the synonyms listed in Wehmeyer's taxonomic treatment have been accepted by later studies or re-examined using molecular data. The oldest name associated with D. eres is Phomopsis velata (Sacc.) Traverso and the editors of Index Fungorum have recently listed $D$. eres as a synonym of $P$. velata along with many other synonyms including names belonging to Chorostate, Cucurbitaria, Diatrype, Phoma, Phomopsis, Sclerophoma, Sclerophomella, and Valsa (Index Fungorum 2014). Considering its status as the generic type and its wide use in the literature, Rossman et al. (2014) proposed to conserve the name Diaporthe eres over all potential synonyms.

Wehmeyer (1933) based his species concept on morphology rather than host association and observed that Diaporthe eres might be regarded as a species complex. Barr (1978) recognised three sections of Diaporthe based on ascospore morphology including Diaporthe section Diaporthe typified by $D$. eres. Although a broad species concept has historically been associated with $D$. eres, the lack of an ex-type or exepitype culture for this generic type species has been a major issue. The incorporation of DNA-sequence-based comparative methods to accurately define the type species is essential to provide a stable platform for the taxonomy of a genus (Crous et al. 2014). The available identifications of $D$. eres in disease reports and other recent phylogenetic studies have been based solely on morphology or more recently on comparison with reference sequences in GenBank. Despite the previous taxonomic definitions based on morphology and host association and recently vouchered sequences, the phylogenetic limits of the $D$. eres species complex are still unknown.

Diaporthe eres has also been regarded as a minor pathogen causing leaf spots, stem cankers and diseases of woody plants in diverse families including the Ericaceae, Juglandaceae, Rosaceae, Sapindaceae, Ulmaceae, Vitaceae and others, mostly in temperate regions worldwide (Vrandečić et al. 2010; Anagnostakis 2007; Thomidis and Michailides 2009; Baumgartner et al. 2013). In addition, it is considered a pathogen with plant health inspection and quarantine significance (Cline and Farr 2006). Several recent disease reports of $D$. eres include cane blight on blackberry in Croatia (Vrandečić et al. 2010), pathogen of butternut (Juglans cinerea) in Connecticut (Anagnostakis 2007), shoot blight and canker disease of peach in Greece (Thomidis and Michailides 2009), stem canker of Salsola tragus in Russia (Kolomiets et al. 2009), on Vaccinium species in Europe (Lombard et al. 2014) and association with wood cankers of grapevines in Croatia (Kaliterna et al. 2012) and in the USA (Baumgartner et al. 2013). It is reported less frequently on herbaceous plants such as the Cucurbitaceae (Garibaldi et al. 2011; Gomes et al. 2013).

The aims of this study are as follows: 1) to define the species limits of $D$. eres and closely related species based on multi-gene genealogies; 2) to designate epitype specimens for $D$. eres and related species including $D$. alnea, D. bicincta, D. celastrina, D. helicis and D. pulla and provide modern descriptions and illustrations with synonyms; and 3) to critically evaluate phylogenetic species concepts in Diaporthe, 
providing insights into the usefulness of various genes within this species complex.

\section{Materials and methods}

Sampling and morphology

Sources of isolates, additional fresh specimens and cultures obtained from contributors are listed in Table 1. Specimens of D. eres were initially collected from Ulmus in Germany and subsequent collections were made from the same host to identify both the sexual and asexual morphs. Morphological descriptions are based on type or epitype specimens and cultures including pycnidia developing on water agar with sterilized alfalfa stems. Digital images were captured and cultural characteristics were observed as described in Udayanga et al. (2014).

\section{DNA extraction, PCR and sequencing}

DNA was extracted and the ITS, EF1- $\alpha$, CAL, TUB and ACT genes were amplified following the protocols outlined by Udayanga et al. (2014). The FG1093 (60s ribosomal protein L37) was amplified using the universal primers for Ascomycota, E1F1 and E3R1 (Walker et al. 2012) following the touch-down PCR protocol outlined by the same study. HIS (Histone-3) genes were amplified as described in Gomes et al. (2013) using the primer pair CYLH3F (Crous et al. 2004b) and H3-1b (Glass and Donaldson 1995). Apn2 primers for Diaporthe were designed and the conditions were optimised as described in this study and amplified under conditions of 95 $\mathrm{C}^{\circ}$ for $1 \mathrm{~min},\left(95^{\circ} \mathrm{C}: 30 \mathrm{~s}, 54{ }^{\circ} \mathrm{C}: 50 \mathrm{~s}, 72{ }^{\circ} \mathrm{C}: 1 \mathrm{~min}\right) \times 39 \mathrm{cy}-$ cles, $72^{\circ} \mathrm{C}$ for 10 min extension in PCR mixtures used for the other genes in Udayanga et al. (2014). PCR products were visualised in $1 \%$ agarose gel electrophoresis (Udayanga et al. 2014) and then purified with ExoSAP-IT (USB Corp., Cleveland, Ohio) according to the manufacturer's instructions and sequenced with the BigDye Terminator 3.1 cycle sequencing kit (Applied Biosystems, Foster City, California) on an Applied Biosystems 3130xl Genetic Analyser using the same amplification primers for each of the gene regions.

Apn2 (DNA lyase) primer design and assessment of utility within Diaporthe

An alignment of the complete sequences of Apn2-Mat genes of Diaporthe W and G types in Kanematsu et al. (2007) (AB199324-27) with a selected set of homologous Apn2 genes available in GenBank including Colletotrichum caudatum (JX076930-32), C. cereale (EU365102, 365045, 365117), C. fragariae (FR719119), C. fructicola (FR719124), C. gloeosporioides (FR719121-22,
FR719126), C. siamense (FR719125), and Thielavia terrestris chromosome A (XM003651303), Myceliophthora thermophila Chromosome 1 (CP003002), and the mating type A locus from Neurospora terricola (HE600070), $N$. pannonica (HE600067) and N. africana (HE600066) were used to design the forward and reverse primers to amplify the Apn2 gene. The target fragment contained the DNA-(apurinic or apyrimidinic site) lyase (Apn2) gene approximately $800 \mathrm{bp}$ including an intron region of 70-100 bp. The forward primer (apn2fw2: GCMATGTTYGAMATYCTGGAG) and the reverse primer (apn2rw2: CTT GGTCTCCCAGCAGGTG $\mathrm{AAC}$ ) were designed based on the proximal end of first exon and the distal end of the second exon region relatively conserved across the alignment. The selected primers were then evaluated for thermal properties, GC content, hairpin formation and self-complementarities using the online platforms of OligoCalc (http://www.basic.northwestern.edu/biotools/ oligocalc.html) and the Sequence Manipulation Suite (http:// www.bioinformatics.org/sms $2 /$ pcr_primer_stats.html).

Gradient PCR and reagent optimisations were used to develop the standard protocols for amplification. Twelve reactions across an annealing temperature gradient of $65-50{ }^{\circ} \mathrm{C}$ for each of the test isolates were performed in three replicates. The optimal annealing temperature was determined by the intensity of the amplicons visualised by agarose gel electrophoresis. Primers were initially tested against a panel of 20 species selected from a broad range of Diaporthe species and including the representative isolates of Ophiodiaporthe cyatheae (AR5192) and Mazzantia galii (AR4658). PCR products were purified and sequenced using the protocols detailed above.

Sequence alignment and phylogenetic analysis

Raw sequences were assembled with Sequencher 4.9 for Windows (Gene Codes Corp., Ann Arbor, Michigan). The consensus sequences were then initially aligned using MAFFTv.7 (Katoh and Standley 2013) (http://mafft.cbrc.jp/ alignment/server/) and optimised in the SATEv.2.2.7 (Simultaneous Alignment and Tree Estimation) high throughput alignment platform (http://phylo.bio.ku.edu/ software/sate/sate.html) (Liu et al. 2012). Newly generated ITS and EF1- $\alpha$ sequences were analysed with all available type-derived sequences listed in Udayanga et al. (2011, 2012a) and Gomes et al. (2013) to determine initial identities of the isolates.

ML gene-trees were estimated using the software RAxML 7.4.2 Black Box (Stamatakis 2006; Stamatakis et al. 2008) in the CIPRES Science Gateway platform (Miller et al. 2010). For the concatenated dataset all free modal parameters estimated by RAxML with ML estimate of 25 per site rate categories. The RAxML software accommodated the GTR model of nucleotide substitution with the additional options 


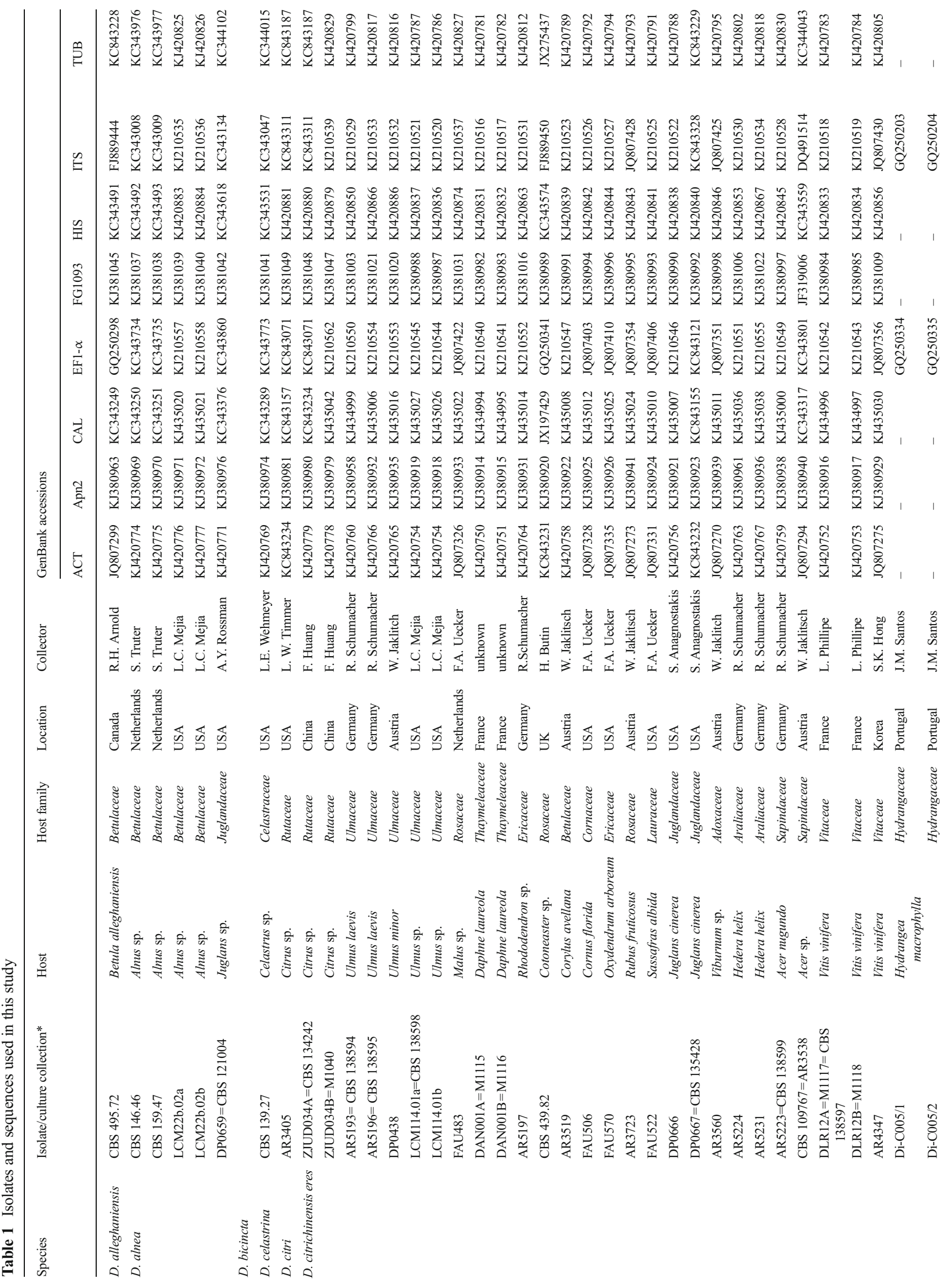




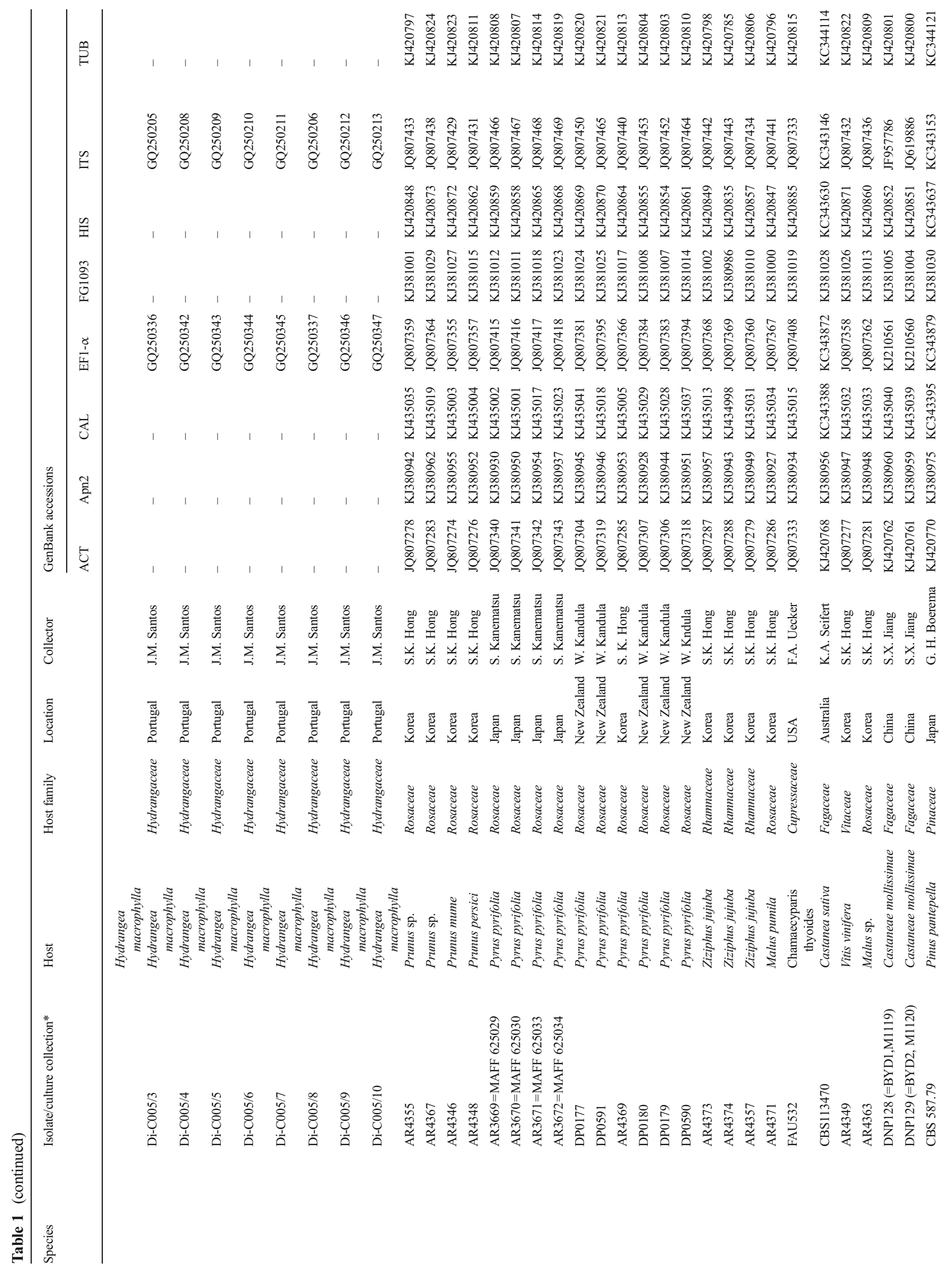


of modeling rate heterogeneity $(\Gamma)$ and proportion invariable sites (I). These analyses utilised the rapid bootstrapping algorithm in RAxML. All isolates were subjected to a multi-gene analysis of seven genes including Apn2, EF1- $\alpha$, CAL, HIS, FG1093, ACT and TUB regions, excluding the ITS region from the combined analysis. Individual datasets were tested for congruency using the $70 \%$ reciprocal bootstrap (BS) threshold method as described by Gueidan et al. (2007).

Evolutionary models for phylogenetic analyses were selected independently for each locus using MrModeltest 2.3 (Nylander 2004) under the Akaike Information Criterion (AIC) implemented in both PAUP v.4.and MrBayes v3. Phylogenetic reconstructions of concatenated and individual gene-trees were performed using both Bayesian (BI) Markov Chain Monte Carlo and Maximum Likelihood (ML) criteria. Bayesian reconstructions were performed using MrBayes 3.1.2 (Huelsenbeck and Ronquist 2001; Ronquist et al. 2005). Six simultaneous Markov chains were run for 1000000 generations with increments of additional generations when needed until the standard deviation of split frequencies are reached to 0.01 and trees are converged and trees were sampled every 100th generation resulting in 10000 total trees. The first $25 \%$ of the trees, representing the burn-in phase of the analyses, were discarded and the remaining trees used for calculating posterior probabilities (PP) in the majority rule consensus tree. PAUPv $4.0 \mathrm{~b} 10$ was used to conduct maximum parsimony analyses. Trees were inferred using the heuristic search option with 1000 random sequence additions. The Maxtrees option was unlimited, branches of zero length were collapsed and all equally parsimonious trees were saved. Maximum parsimony trees generated were compared with BI and ML trees, with bootstrap support values indicated on the trees shown. Phylogenetic trees and data files were viewed in MEGA 5 (Tamura et al. 2011), Treeview (Page 1996) and Fig tree v1.4 (Rambaut and Drummond 2008). All the sequences generated were deposited in GenBank (Table 1) and alignments and trees in TreeBASE (Study 16003) and typifications (MBT178529-178541) in MycoBank (Crous et al. 2004a).

Phylogenetic species recognition

In order to determine the species boundaries, we applied the criteria previously described by Dettman et al. (2003a). Clades were genealogically concordant if they were present in at least some of the gene trees and genealogically non-discordant if they were strongly supported (MP $\geq 70 \% ; \mathrm{ML} \geq 70 \%$ ) in a single gene and not contradicted at or above this level of support in any other single gene tree. This criterion prohibited poorly supported non-monophyly at one locus from undermining well-supported monophyly at another locus. In addition, species limits were determined conclusively if resolved with strong support ( $\mathrm{PP} \geq .95 ; \mathrm{ML} \geq 70 \% ; \mathrm{MP} \geq 75 \%$ ) in all analyses of the combined seven gene dataset (excluding 
ITS). Since the variability of ITS sequences within the $D$. eres clade resulted in confusion, also confirmed by Santos et al. (2010), we opted to use the combined seven gene alignment to reconstruct the evolutionary relationships.

When deciding which independent evolutionary lineages should be ranked as phylogenetic species, genetic differentiation and exhaustive subdivision criteria were applied (Dettman et al. 2003a, 2006). Genetic differentiation required that lineages be well-differentiated, preventing minor terminal lineages from being recognised as phylogenetic species. Exhaustive subdivision required that all individuals be classified into phylogenetic species and no individuals be left unclassified. The technique involved tracing from the terminal nodes of the tree, collapsing all lineages that were not subtended by an independent evolutionary lineage (Dettman et al. 2006; Laurence et al. 2014).

Testing phylogenetic informativeness

To determine loci most suitable for species level phylogenetic inference in closely related species within Diaporthe, we employed the phylogenetic informativeness profiling method (Townsend 2007) implemented in PhyDesign (LopezGiraldez and Townsend 2011 , http:// phydesign.townsend.yale.edu/). Phylogenetic informativeness (PI) was measured from a partitioned combined dataset of ten ex-types and taxonomically authenticated species for the ITS, EF1- $\alpha$, TUB, CAL, ACT, HIS, FG1093 and Apn2 genes. The maximum likelihood tree from RAxML analysis of the concatenated data set was ultrametricised using Mesquite (Maddison and Maddison 2011). Per gene and per site informativeness for all partitions were determined using PhyDesign and the rates of change for each site determined under the HyPhy criteria (Pond et al. 2005).

\section{Results}

DNA Sequencing, Apn2 new primers and phylogenetic analyses

Four hundred new sequences were generated in this study (Table 1) from 68 living cultures of Diaporthe for eight genes (ACT, Apn2, CAL, EF1- $\alpha$, HIS, FG1093, ITS and TUB). Additional sequences were obtained from GenBank. Evaluation of the newly designed Apn2 primers (apnfw2/apanrw2) determined that the melting temperatures $\left(\mathrm{T}_{\mathrm{m}}\right)$ of apn $2 \mathrm{fw} 2=$ $49-56{ }^{\circ} \mathrm{C}$ and apn2rw $2=58.6{ }^{\circ} \mathrm{C}$ with $\mathrm{GC}$ content of apn $2 \mathrm{fw} 2=38-57 \%$ and apn2rw $2=59 \%$. No hairpin formation or self-complementarities were found. The optimal annealing temperature for the primer pair was determined to be $54{ }^{\circ} \mathrm{C}$ by the by gradient PCR using amplification conditions outlined in materials and methods. Amplification and sequencing of 20 different isolates of Diaporthe outside of the D. eres species complex (GenBank accessions KM016673KM016694) including additional isolates of Ophiodiaporthe cyatheae (AR5192, KM016693) and Mazzantia galii (AR4658, KM016692) were successful (Supplementary material 1/ESM 1).

Eight different alignments corresponding to each individual gene, a combined alignment of all eight genes, and a combined alignment of the seven genes excluding the ITS were analysed. Comparison of the alignment properties and nucleotide substitution models are provided in Table 2. Phylogenetic trees inferred from EF1- $\alpha$ and ITS sequences for all isolates, a summary of the results of GCPSR in RAxML cladogram and a phylogram of combined analysis of seven genes are presented with annotations for species, host and geographic origin (Figs. 1, 2, 3).

Single gene analyses and comparison

The ITS and EF1- $\alpha$ sequence alignment consisted of 548 and 369 characters respectively, with 78 isolates including the outgroup taxa. Phylogenetic trees obtained from maximum likelihood (ML), parsimony (MP), and Bayesian (BI) analysis were compared for the placement of each isolate, topology of the tree and clade stability. The topology of the ML tree inferred from RAxML was identical to BI and MP trees with reference to the major subclades and is presented as Fig. 1 Alignment properties and model selections are shown in Table 2.

The ITS phylogeny has limited resolution within the species complex often resulting in an inconclusive branching order and lack of bootstrap support at the internodes, resulting in two major clusters. Analysis of each region of the ITS sequences of Diaporthe eres with the reference annotated sequence (KC343073) revealed an approximately $176 \mathrm{bp}$ span for ITS1 and $161 \mathrm{bp}$ for ITS2 region with the intermediate $5.8 \mathrm{~s}$ rDNA partition spanning approximately $157 \mathrm{bp}$. The differences within two ITS1 clusters were consistent although the two clusters were not completely congruent with the ITS2 region.

We obtained two different isolates from a single ascospore and conidium (AR5193, AR5196) derived from two twigs of Ulmus collected at the same time from the same individual tree in Germany, where the field collections were made. Both of these isolates were determined to be $D$. eres based on morphology of the asexual and sexual morphs. However, the single ascospore-derived isolate (AR5193) and the single conidium-derived isolate (AR5196) had different ITS sequences and were placed in different major groups in the ITS phylogenetic tree (Fig. 1). However, they were determined to be the same species based on EF1- $\alpha$ and all other genes. 
Table 2 Alignment properties and nucleotide substitution models

\begin{tabular}{|c|c|c|c|c|c|c|c|c|c|}
\hline Genes/loci & ITS & $\mathrm{EF} 1-\alpha$ & CAL & TUB & $\mathrm{ACT}$ & FG1093 & HIS & Apn2 & combined 7 genes \\
\hline $\begin{array}{l}\text { Characters included in } \\
\text { analysis (with gaps) }\end{array}$ & 548 & 369 & 429 & 517 & 259 & 379 & 501 & 769 & 3193 \\
\hline $\begin{array}{l}\text { Characters excluded in } \\
\text { analysis }\end{array}$ & - & - & 101 & - & - & - & - & - & 101 \\
\hline Invariable characters & 479 & 266 & 309 & 434 & 186 & 263 & 381 & 645 & 2563 \\
\hline $\begin{array}{l}\text { Parsimony informative } \\
\text { characters }(\%)\end{array}$ & $43(8 \%)$ & $62(16 \%)$ & $45(10 \%)$ & $69(13 \%)$ & $40(15 \%)$ & $44(11 \%)$ & $69(13 \%)$ & $78(10 \%)$ & $427(13 \%)$ \\
\hline $\begin{array}{l}\text { Uninformative variable } \\
\text { characters }\end{array}$ & 26 & 41 & 75 & 14 & 33 & 72 & 51 & 46 & 203 \\
\hline $\begin{array}{l}\text { Nucleotide substitution } \\
\text { models }\end{array}$ & $\mathrm{GTR}+\mathrm{I}+\mathrm{G}$ & $\mathrm{HKY}+\mathrm{G}$ & $\mathrm{GTR}+\mathrm{I}+\mathrm{G}$ & $\mathrm{HKY}+\mathrm{G}$ & $\mathrm{GTR}+\mathrm{I}+\mathrm{G}$ & $\mathrm{HKY}+\mathrm{G}$ & $\mathrm{GTR}+\mathrm{I}+\mathrm{G}$ & $\mathrm{HKY}+\mathrm{G}$ & $\mathrm{GTR}+\mathrm{I}+\mathrm{G}$ \\
\hline
\end{tabular}

Inspection of the ITS alignment also revealed that isolates can share similarity in the ITS1 and ITS2 regions both within and between species in this complex. The ITS1 region of Diaporthe vaccinii is identical to most of the isolates identified as D. eres. In contrast, the ITS2 region is different between the two species. Diaporthe citri and D. citrichinensis share ITS similarities with the other species in the complex. However, the two species are clearly diverged when analyses using the other genes are performed and therefore regarded as outgroup taxa in the analyses.

As opposed to the ITS, the EF1- $\alpha$ phylogenetic tree clearly distinguishes species boundaries except in a few closely related species that could only be distinguished in the combined analyses. The EF1- $\alpha$ phylogenetic tree was used as an initial guide to determine the species limits and tested with all other genes and in various combinations. Nodes that were supported $(\geq 70 \%$ ) in the EF1- $\alpha$ phylogeny were initially recognised as species to be later confirmed by the strict application of GCPSR criteria. Comparison of each single gene phylogeny revealed that the isolates recognised as $D$. eres in the EF1- $\alpha$ phylogeny grouped together with significant bootstrap support with the other genes; however, minor genetic variation was always present in the species recognised in combined tree. Also according to the genealogical non-discordance, the distinct ITS groups could only be recognised as poorly supported clades contradicted by the other gene trees and therefore were not supported as distinct phylogenetic species (Fig. 1).

Genealogical concordance phylogenetic species recognition

The combined sequence alignment of seven genes comprised 3293 total characters for 68 isolates. An ambiguously aligned region of $100 \mathrm{bp}$ in the CAL gene (26772777) in the combined alignment, was excluded from the analysis. The phylogenetic tree inferred from ML analysis was identical to the Bayesian and parsimony trees in terms of major clades and branching order. A total of 25 independent evolutionary lineages were recognised based on given criteria of the ML/MP $\geq 70 \%$ bootstrap support in single genes and are summarised on the combined cladogram (Fig. 2). Lineage 11 was only supported by the tubulin gene tree and contradicted by all seven other gene trees including ITS and lineage 13 was poorly supported by the combined tree and contradicted in all single gene trees. Therefore the two lineages were excluded under genealogical non-discordance criterion. The other lineages were supported by more than one gene at the same level as in the EF1- $\alpha$ tree (Fig. 1) and when not supported in a gene tree, they were not contradicted. Therefore these lineages were selected under genealogical concordance criterion for further analysis to determine the species limits.

To fulfill the genetic differentiation criterion, the terminal lineages $1,2,3,6,9,10,11,12,15,17,20,22$ and 24 (blue numbers) in the combined analysis were excluded from the exhaustive subdivision process (Fig. 2). The remaining 11 lineages were used in the exhaustive subdivision process, which involved tracing from the terminal nodes of the tree. All lineages not subtended by an independent evolutionary lineage were collapsed, to satisfy that all individuals should be classified and none remained unclassified. To satisfy the exhaustive subdivision criterion, poorly supported lineage numbers 4, 5, 8 were collapsed under lineage number 7, which is supported by all seven genes and combined analysis, to recognise phylogenetic species 1 (PS 1). The PS 2 and PS 3 were recognised based on the support of each single gene trees as distinct sister taxa

Fig. 1 Comparison of the ITS and the EF1- $\alpha$ phylogenetic trees: The phylograms resulted from RAxML analysis of a) ITS and b) EF1- $\alpha$ regions. The ML, MP bootstrap values $\geq 70 \%$, bayesian $P P \geq 0.75$ are indicated above the branches. The trees are rooted with Diaporthe citri (AR3405). The sequences of Di-C005/1-10 (green) were obtained from Santos et al. 2010. Ex-type and ex-epitype cultures are in bold 


\section{a ITS}

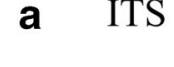

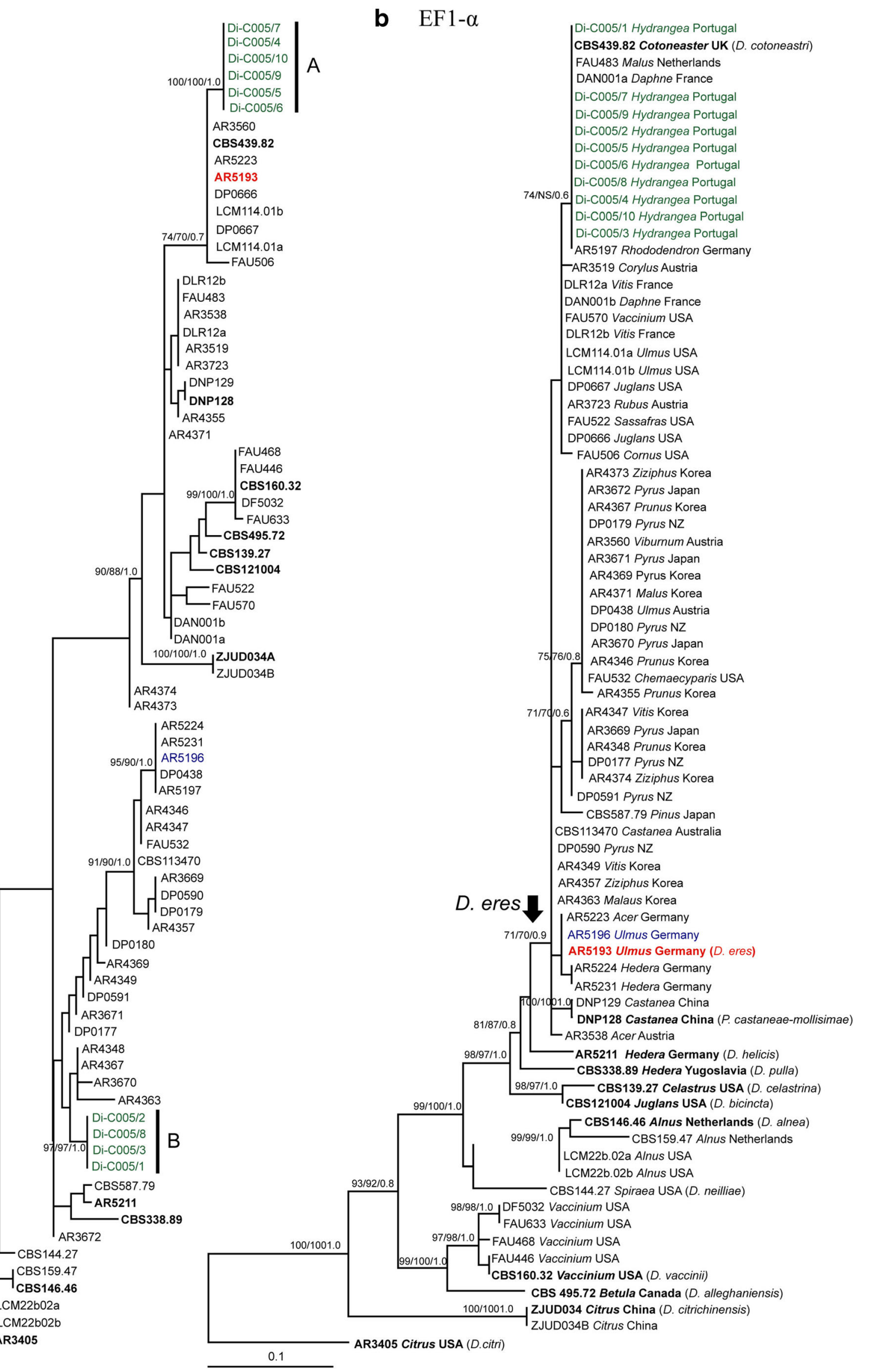




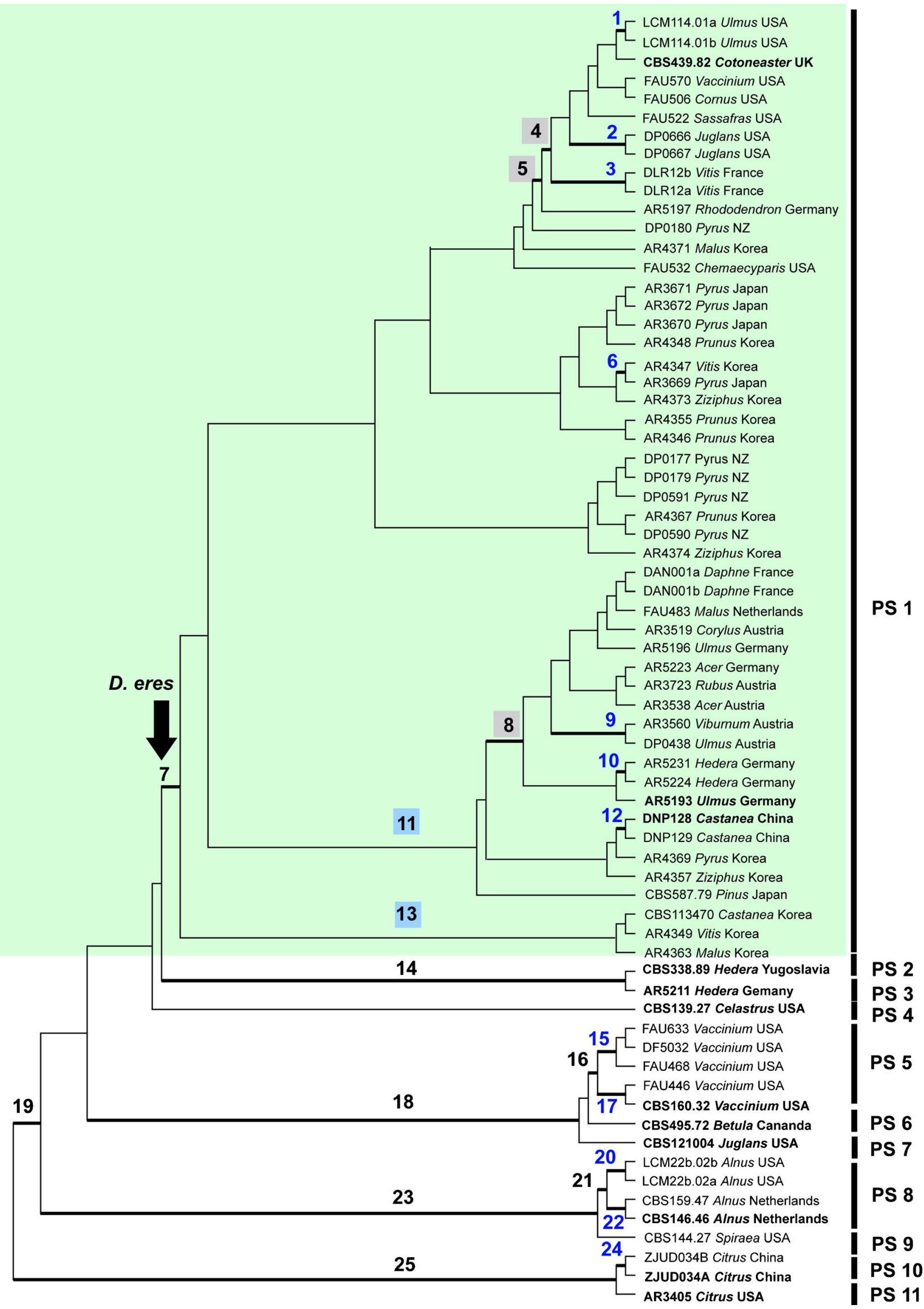


4 Fig. 2 The summary of independent evolutionary lineages recognised based on genealogical concordance, genealogical non-discordance criteria and ranking according to genetic differentiation and exhaustive subdivision indicated on the RAxML cladogram based on combined analysis of 7 genes (ACT, Apn2, CAL, EF1- $\alpha$, HIS, FG1093 and TUB). Taxon labels indicate strain number, host and country. Labels to the right the branch labels indicate phylogenetic species identified by the analyses. Bold branches numbered in blue and black were supported by the majority of the loci or supported by at least one locus but not contradicted by any other locus. The non bold branches numbered with blue fill squares (11 and 13) indicate branches that were poorly supported in combined analysis and contradicted in single gene trees. The terminal branch numbers (blue) were excluded from the ranking process under the genetic differentiation criterion. The bold branches numbered with grey fill squares $(4,5$ and 8$)$ are collapsed under branch 7 in the exhaustive subdivision process. PS 1- PS 11 indicates the phylogenetic species recognised by genealogical non-discordance and exhaustive subdivision. The limit of PS 1 is indicated by a down arrow at number 7 selected through exhaustive subdivision; with green shade indicates all the isolates belong to $D$. eres

represented by singletons. PS 4-PS 11 were recognised based on exhaustive subdivision of the rest of the lineages later assigned to distinct species based on placement of ex-type and ex-epitype isolates.

The tree generated from the RAxML analysis was used to represent the phylogeny annotated with host and geographic origin of the each isolate and determination of species (Fig. 3). The phylogenetic species recognised in the above analyses (PS 1-PS 11) (Fig. 2) were assigned to named species based on ex-type and ex-epitype isolates and supported with morphological studies of all available isolates. The species determination was highly similar. The EF1- $\alpha$ phylogenetic tree and the clade credibility values of each of the methods increased when compared to the EF1- $\alpha$ phylogenetic tree with a relatively stable tree topology. The limit of $D$. eres was determined based on the well-supported node at lineage number 7 assigned as PS 1 in the combined phylogenetic tree with application of GCPSR criteria. Therefore, a total of nine phylogenetic species were recognised within the species complex, as follows: PS 1 as $D$. eres, PS 2 as $D$. pulla, PS 3 as D. helicis, PS 4 as D. celastrina, PS 5 as D. vaccinii, PS 6 as D. alleghaniensis, PS 7 as D. bicincta, PS 8 as $D$. alnea, PS 9 as D. neilliae when using two closely related species, D. citri (PS 11) and D. citrichinenesis (PS 10) as out-group taxa in the combined analysis (Fig. 2). Therefore, the limit of the $D$. eres species complex was determined to correspond to node 19 in Fig. 2, with nine accepted species, and D. citri and D. citrichinensis as basal lineages. Diaporthe pulla (PS 2) and D. helicis (PS 3) appeared to be closely related sister taxa and were closely related to $D$. eres (PS 1). However, based on the comparison of each single gene tree, these two species diverged from $D$. eres and each should be recognised as distinct phylogenetic species.
Phylogenetic informativeness of each locus

The informativeness profiles indicated that the EF1- $\alpha$, Apn2 and HIS genes are the best markers to resolve the phylogenetic species included in this analysis (Fig. 4). The EF1- $\alpha$ and ACT genes performed the best in terms of phylogenetic informativeness per site. In comparison with the percentage parsimony informative characters of each gene (Table 2), EF1- $\alpha$ (16\%) and ACT (15\%) regions show a congruent result with the phylogenetic informativeness per site.

\section{Taxonomy}

Based on the phylogenetic analyses, the type species of Diaporthe, D. eres, is circumscribed along with eleven closely related but phylogenetically distinct lineages, each of which is briefly described and illustrated. If a modern description already exists, a reference is given and the species is provided with host association, distribution and notes on taxonomy and phylogeny. As listed after the descriptions, type and additional specimens were observed for each species. Epitype specimens were designated for six species. In addition, ex-type, exepitype, and additional cultures were observed, if available.

Diaporthe eres Nitschke, Pyrenomycetes Germanici 2: 245 (1870), nom. cons. prop. Fig. 5

= Phoma oblonga Desm., Annls Sci. Nat., Bot., sér. 3, 22: 218 (1853)

$\equiv$ Phomopsis oblonga (Desm.) Traverso, Fl. ital. crypt., Pars 1: Fungi. Pyrenomycetae. Xylariaceae, Valsaceae, Ceratostomataceae: 248 (1906)

$=$ Phomopsis cotoneastri Punith., Trans. Br. mycol. Soc. 60: 157 (1973)

$\equiv$ Diaporthe cotoneastri (Punith.) Udayanga, Crous \& K.D. Hyde, Fungal Diversity 56: 166 (2012)

=Phomopsis castaneae-mollisimae S.X. Jiang \& H.B. Ma, Mycosystema 29: 467 (2010)

$\equiv$ Diaporthe castaneae-mollisimae (S.X, Jiang \& H.B. Ma) Udayanga, Crous \& K.D. Hyde Fungal Diversity 56: 166 (2012)

= Phomopsis fukushii Tanaka \& S. Endô, in Endô, J. Pl. Prot. Japan 13: [1] (1927)

Perithecia on dead twigs 200-300 $\mu \mathrm{m}$ diam, black, globose, subglobose or irregular, densely clustered in groups, deeply immersed in host tissue with tapering necks, 300$700 \mu \mathrm{m}$ long protruding through substrata. Asci (39-) 48.5$58.5(-61) \mu \mathrm{m} \times(6.5-) 7-9(-11) \mu \mathrm{m}(\overline{\mathrm{x}} \pm \mathrm{SD}=53 \pm 5 \times 8.0 \pm 0.7$, $n=30)$, unitunicate, 8 -spored, sessile, elongate to clavate. Ascospores (11-)12.5-14.5(-15.5) $\times 3-4 \mu \mathrm{m}( \pm \mathrm{SD}=13.5 \pm$ $1 \times 3.5 \pm 0.3, n=30$ ), hyaline, two-celled, often 4-guttulate, with larger guttules at centre and smaller ones at the ends, elongated to elliptical. 
Pycnidia on alfalfa twigs on WA, 200-250 $\mu \mathrm{m}$ diam, globose, embedded in tissue, erumpent at maturity, with a 200-300 $\mu \mathrm{m}$ long, black, elongated neck, often with yellowish, conidial cirrus extruding from ostiole, walls parenchymatous, consisting of 3-4 layers of medium brown textura angularis. Conidiophores 10-15×2-3 $\mu \mathrm{m}$, hyaline, smooth, unbranched, ampulliform, straight to sinuous. Conidiogenous cells $0.5-1 \mu \mathrm{m}$ diam, phialidic, cylindrical, terminal, slightly tapering towards the apex. Paraphyses absent. Alpha conidia

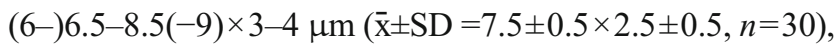
abundant in culture and on alfalfa twigs, aseptate, hyaline, smooth, ovate to ellipsoidal, often biguttulate, base subtruncate. Beta conidia $(18-) 22-28(29) \times 1-1.5 \mu \mathrm{m}(\mathrm{SD}=25$ $\pm 2 \times 1.3 \pm 0.3, n=30$ ), formed in culture and alfalfa stems in some isolates, aseptate, hyaline, smooth, fusiform to hooked, base sub-truncate.

Cultural characteristics: In dark at $25^{\circ} \mathrm{C}$ for $1 \mathrm{wk}$, colonies on PDA fast growing, $5.5 \pm 0.2 \mathrm{~mm} /$ day $(n=8)$, white, aerial, fluffy mycelium, reverse centre dark pigmentation developing in centre; producing abundant, black stromata at maturity.

Host range: Abutilon (Malvaceae), Acer (Sapindaceae), Alliaria (Brassicaceae), Allium (Amaryllidaceae), Arctium (Asteraceae), Castanea (Fagaceae), Chamaecyparis, Juniperus, (Cupressaceae), Corylus (Betulaceae), Cornus (Cornaceae), Cotoneaster, Malus, Prunus, Pyrus, Rubus, Sorbus (Rosaceae), Cucumis (Cucurbitaceae), Daphne (Thymelaeaceae), Fraxinus, Osmanthus (Oleaceae), Hedera (Araliaceae), Hordeum (Poaceae), Ilex (Aquifoiaceae), Juglans (Juglandaceae), Laburnum, Phaseolus, Wisteria (Fabaceae), Laurus, Sassafras (Lauraceae), Magnolia (Magnoliaceae), Opuntia (Cactaceae), Picea, Pinus (Pinaceae), Rhododendron, Vaccinium (Ericaceae), Rumex (Polygonaceae), Skimmia (Rutaceae), Ulmus (Ulmaceae), Viburnum (Adoxaceae), Vitis (Vitaceae), Ziziphus (Rhanmnaceae) (including the host association confirmed with molecular data in Gomes et al. 2013)

Geographic distribution: Austria, China, France, Korea, Germany, Italy, Japan, Latvia, Netherlands, New Zealand, UK, USA

Type material of Diaporthe eres - GERMANY, Nordrhein-Westfalen, Munsterland, Munster Botanical Gardens, on twigs of Ulmus sp., June 1865, T. Nitschke, (B 70 0009145, lectotype designated here; MBT178528, isolectotypes ex herb. Munster; B 70 0009146, B 70 0009147); Carpinion forest, on dead, attached, corticated twigs of Ulmus laevis, 5 January 2013, R. Jarling, comm. R. Schumacher (BPI 892912, epitype designated here, exepitype culture AR5193=CBS 138594; MBT178527).

Phoma oblonga - FRANCE, on twigs of Ulmus campestris, unknown collector (bound specimen of Desmazieres, Plantes Cryptogames du Nord de la France, Ed. 2, ser. 2. No. 60 in BPI, lectotype designated here; MBT178529). GERMANY, Carpinion forest, on dead, attached, corticated twigs of Ulmus laevis, 5 January 2013, R. Jarling, comm. R. Schumacher (BPI 892913, epitype designated here, ex-epitype culture AR5196=CBS 138595; MBT178530).

Phomopsis castaneae-mollisimae - CHINA, Taian, Shangdong, leaf of Castanea mollissima, April 2006, S.X. Jiang (CLS 0612, holotype not seen, ex-type culture BYD1= DNP128 observed), ex-isotype culture BYD4=DNP129.

Diaporthe cotoneastri - UK, Scotland, Ayr, on Cotoneaster sp., May 1982, H. Butin (isotype CBS-H 7633 not seen, ex-isotype culture CBS 439.82 observed).

Phomopsis fukushii JAPAN, Ibaraki, on Pyrus pyrifolia, August 1994, S. Kanematsu, (BPI 892933, neotype designated here, ex-neotype culture MAFF625034=AR3672; MBT178531).

Additional material examined: AUSTRALIA, New South Wales, on Castanea sativa (chestnuts in store), 5 July 1999, K.A. Seifert 932 (culture CBS 113470=DAOM 226800); AUSTRIA, Vienna, 21st District, Marchfeldkanalweg, grid square 7764/2, on dead twigs of Ulmus minor, 17 November 2002, W. Jaklitsch WJ 2021 (BPI 843626, culture DP0438); Vienna, 22nd District. Lobau (Oelhafen), grid square 7865/1, on dead stems of Acer campestre, 21 October 2000, W. Jaklitsch WJ 1643 (BPI 748435, culture AR3538); Niederoesterreich, Buschberg, grid square 7464/1, on Rubus fruticosus, 11 August 2001. W. Jaklitsch WJ 1771 (BPI 843611, culture AR3723); Niederoesterreich, Losenheim, Laerchkogel, on Corylus avellena, 30 September 2000, W. Jaklitsch WJ 1605 (BPI 747936, culture AR3519=CBS 109497); Wograda, St. Margareten, Kaernten, grid square 9452/3, on Viburnum lantana, 27 October 2000, W. Jaklitsch WJ 1662, (BPI 749133, culture AR3560); FRANCE, on Daphne lauriola (culture DAN001a= M1115), ibid, DAN001b=M1116; on Vitis vinifera, Larignon Phillipe (culture DLR12A=M1117= CBS 138597, DLR12B= M1118); GERMANY, mixed forest, on dead twigs of Acer nugundo, 13 April 2013, R. Jarling, comm. R. Schumacher (culture AR5223= CBS 138599); on dead attached twigs of Hedera helix, 26 March 2013, R. Jarling, comm. R. Schumacher (culture AR5224); Planar forest, on attached bud of Rhododendron sp., 3 January 2013, comm. R. Schumacher (culture AR5197); JAPAN, Ibaraki, on Pyrus pyrifolia, S. Kanamatsu, August 1994 (culture AR3670=MAFF625030, AR3671 =MAFF625033, AR3669=MAFF625929); on Pinus pantepella, G.H. Boerema, May 1979 (CBS-H 16732, alfalfa stem in culture BPI 892918, culture CBS587.79); KOREA, Eumsnus, on Prunus persica, S.K. Hong, Pho 0348 (culture AR4355); Punggi-eup, on Malus pumila var. dulcissima, S.K. Hong, BD 102 (culture AR4371); Anseong-si, on Ziziphus jujube, S.K. Hong, Pho 0345 (culture AR4373), KOREA: Geumsan-gun, on Ziziphus jujube, S.K. Hong, Pho 0330 (AR4374); Bubal-eup, on Prunus mume, S.K. Hong, BD 173 (culture AR4346); on Vitis vinifera, S.K. Hong (culture AR4347); on Chamaecyparis thyoides, F.A. Uecker (culture FAU 532); on Ziziphus jujuba (culture AR4357); on Pyrus 
pyrifolia, S.K. Hong (culture AR4369); on Vitis sp., S.K. Hong (culture AR4349); on Prunus persici, S.K. Hong (culture AR4348); on Prunus sp. (culture AR4367); on Malus sp., S.K. Hong (culture AR4363); NETHERLANDS, on branches of Malus sp. (culture FAU483); NEW ZEALAND, Waikato region, on Pyrus pyrifolia (Cultivar - Nashi Asian Pear) (culture DP0179, DP0177, DP0180); on Pyrus pyrifolia, W. Kandula WK-NP204 (culture DP0590); on Pyrus pyrifolia, W. Kandula WK-NP-104 (culture DP0591); USA, New York, Adirondack Mountains, Buttermilk Falls, on twigs of Ulmus sp., 7 June 2007, L.C. Mejia (culture LCM114.01a=CBS 138598, LCM114.01b); New Jersey, on Sassafras albida (culture FAU522); Virginia: on Oxydendrum arboreum (culture FAU570); Maryland, on Cornus florida (culture FAU506); North Carolina, Old Fort, on bark from canker on Juglans cinerea, June 2002, S. Anagnostakis (cultures DP0666, DP0667).

Notes: Diaporthe eres was designated as the type species by Nitschke (1870) and this has been widely accepted in the literature (Wehmeyer 1933; Barr 1978; Brayford 1990; Rossman et al. 2007). The asexual morph of $D$. eres has been known as Phomopsis oblonga (basionym: Phoma oblonga (Wehmeyer 1933; Udayanga et al. 2011). Considering the obscurity of the older names listed as synonyms in Wehmeyer (1933) and the difficulty of determining their identity within the genus Diaporthe, Rossman et al. (2014) proposed to conserve the name $D$. eres over these older synonyms.

Originating from the same host and country as the lectotype, an epitype of $D$. eres is here designated. Many recent collections and isolates included in the phylogenetic analysis were from the same and different hosts in Germany and throughout the temperate regions of the world. The diagnostic morphological features of $D$. eres are the black stroma, perithecia generally immersed in the host tissue with necks protruding through ruptured host tissue with large asci (48.5$58.5 \mu \mathrm{m} \times 7-9 \mu \mathrm{m})$ and ascospores $(12.4-14.4 \times 3-4 \mu \mathrm{m})$ compared to other species of Diaporthe. Among the cultures used in this study, the majority sporulated on PDA or WA+ alfalfa stems producing abundant black pycnidia and conidial masses. Only alpha conidia were observed in some cultures while both alpha and beta conidia were abundant in other cultures. The sexual morph was not observed in culture. Significant morphological differences were not observed in cultures of different ITS types or cultures derived from different hosts. The geo-ecological data for isolates identified here as $D$. eres suggest that this species has a widespread distribution and a broad host range as a pathogen, endophyte or saprobe (Toti et al. 1993; Sieber and Dorworth 1994; Vajna 2002; Sieber 2007; Casieri et al. 2009).

Diaporthe alleghaniensis R.H. Arnold, Can. J. Bot. 45: 787 (1967). Fig. 6a-c

Pycnidia on alfalfa twigs on WA 100-200 $\mu \mathrm{m}$ diam, globose, embedded in tissue, erumpent at maturity, with a slightly elongated neck 100-180 $\mu \mathrm{m}$ long, black, often with yellowish, conidial cirrus extruding from ostiole, walls parenchymatous, consisting of 3-4 layers of medium brown textura angularis. Conidiophores $9-15 \times 1-2 \mu \mathrm{m}$, hyaline, smooth, unbranched, ampulliform, cylindrical to sub-cylindrical. Conidiogenous cells $0.5-1 \mu \mathrm{m}$ diam, phialidic, cylindrical, terminal, slightly tapering towards apex. Paraphyses absent. Alpha conidia $7-9 \times 3-4 \mu \mathrm{m}(\overline{\mathrm{x}} \pm \mathrm{SD}=8 \pm 0.5 \times 3.5 \pm 0.3, n=30)$, abundant in culture and on alfalfa twigs, aseptate, hyaline, smooth, ovate to ellipsoidal, biguttulate or multiguttulate, base sub-truncate. Beta conidia not observed.

Cultural characteristics: In dark at $25^{\circ} \mathrm{C}$ for $1 \mathrm{wk}$, colonies on PDA fast growing, $5.8 \pm 0.2 \mathrm{~mm} /$ day $(n=8)$, white, aerial mycelium with concentric rings, reverse grey pigmentation developing in centre; stroma not produced in $1 \mathrm{wk}$ old cultures.

Type material: CANADA, Ontario, Abinger Township, Lennox and Addington Co., Vennacher, P.S.P. 10, on branch of Betula lenta, 16 September 1953, R. Horner, J. Newman, A.W. Hill (DAOM 45776, holotype not seen, ex-type culture CBS 495.72 observed).

Host range: On dead branches of Betula alleghaniensis (Betulaceae).

Geographic distribution: Canada (Ontario), also reported from New Brunswick, Quebec, USA (NH, NY, VT) by Arnold (1967).

Notes: Based on phylogenetic analyses, Diaporthe alleghaniensis is clearly distinguished from closely related cryptic taxa. It was recognised as a facultative parasite of yellow birch (Betula alleghaniensis) on which it causes an annual bark canker and foliage disease (Arnold 1967). According to the protologue, it is morphologically distinguished from Diaporthe eres based on the narrow cylindrical asci each with a truncate apex and the narrow cylindrical-ellipsoid ascospores with a variable position of the single septum. However, conidia in culture could not be distinguished from those of $D$. eres.

Diaporthe alnea Fuckel, Jahrb. nassau. Ver. Naturk. 2324: 207 (1870) Fig. 6d-n

= Phomopsis alnea Höhn., Sber. Akad. Wiss. Wien, Math.naturw. Kl., Abt. 1 115: 681 (1906)

Perithecia on dead twigs 200-300 $\mu \mathrm{m}$ diam, black, globose to conical, scattered evenly on dead twigs, immersed in host tissue with elongated, $300-400 \mu \mathrm{m}$ long necks, protruding through substrata in clusters. Asci 36-46 $\mu \mathrm{m} \times 6-7 \mu \mathrm{m}$ $(\overline{\mathrm{x}} \pm \mathrm{SD}=40 \pm 5 \times 6.5 \pm 0.7, n=30)$, unitunicate, 8 -spored, sessile, elongate to clavate. Ascospores (11-)12.5-13.5(-14) $\times$ 2.5-3 $\mu \mathrm{m}(\overline{\mathrm{x}} \pm \mathrm{SD}=12.7 \pm 0.8 \times 2.8 \pm 0.3, n=30)$, hyaline, twocelled, often 4-guttulate, with larger guttules at centre and smaller ones at ends, elongated to elliptical.

Pycnidia on alfalfa twigs on WA 100-200 $\mu \mathrm{m}$ diam, globose to subglobose, embedded in tissue, erumpent at maturity, with black, 100-200 $\mu \mathrm{m}$ long necks, cream, conidial cirrus 
extruding from ostiole; walls parenchymatous, consisting of 3-4 layers of medium brown textura angularis. Conidiophores 9-16×1-2 $\mu \mathrm{m}$, hyaline, smooth, unbranched, ampulliform, cylindrical to sub-cylindrical, with larger basal cell. Conidiogenous cells $0.5-1 \mu \mathrm{m}$ diam, phialidic, cylindrical, terminal, slightly tapering towards apex. Paraphyses absent. Alpha conidia $8-10 \times 2-3 \mu \mathrm{m}(\overline{\mathrm{x}} \pm \mathrm{SD}=9 \pm 0.5 \times 2.5 \pm 0.2$, $n=30$ ), abundant in culture and on alfalfa twigs, aseptate, hyaline, smooth, ellipsoidal, biguttulate or multiguttulate, base subtruncate. Beta conidia not observed.

Cultural characteristics: In dark at $25^{\circ} \mathrm{C}$ for $1 \mathrm{wk}$, colonies on PDA fast growing, $6 \pm 0.2 \mathrm{~mm} /$ day $(n=8)$, white, aerial mycelium turning grey at edges of plate, reverse yellowish pigmentation developing in centre; stroma not produced in 1 wk old culture.

Host range: On species of Alnus including A. glutinosa, A. rugosa and A. sinuata (Betulaceae)

Geographic distribution: Europe (Germany, Netherlands), USA

Type material: GERMANY, on twigs of Alnus glutinosa, 1894, L. Fuckel (FH, Fungi rhenani 1988, lectotype designated here; MBT178532); Hesse, Oestrich, Alnus glutinosa, 1894, L. Fuckel (BPI 615718, Isolectotype); NETHERLANDS, on Alnus sp., June 1946, S. Truter 605 (BPI 892917, epitype designated here, ex-epitype culture CBS 146.46; MBT178534).

Additional material examined: CZECH REPUBLIC, Moravia, Sternberg, on Alnus glutinosa, February 1922, J. Piskor (BPI 615717); USA, Idaho, Moscow Mtns., on dead stem of Alnus sinuata, 2 July 1898, C.V. Piper (BPI 616606); Maine, North New Portland, on twigs of Alnus rugosa, 3 August 2006, L.C. Mejia (culture LCM22b.02a); Maryland, Takoma Park, on Alnus sp., 1 July 1918, C.H. Kauffman (BPI 615716); Michigan, Isle Royale, Rock Harbor, on Alnus sp., 15 July 1904, E.T. Harper, Susan A. Harper (BPI 616605); New York, Tripoli, Ft. Ann, on Alnus sp., 28 June 1914, S.H. Burnham 104 (BPI 615284).

Notes: Diaporthe alnea is represented here by isolates on Alnus glutinosa from Europe and A. rugosa in the USA. The geographic origins of CBS isolates of $D$. alnea were previously uncertain although the collector's name is known as S. Truter (Gomes et al. 2013). Truter's (1947) doctoral dissertation concerned the die-back of European alder and presumably the collections originated in the Netherlands or close by in Europe. Herein, D. alnea is epitypified with one of Truter's isolates based on the historical authenticity and the morphological similarity of this isolate to the type specimen.

The name Diaporthe nivosa Ellis \& Everh. has been applied to an ascomycete from Alnus in the USA. However, observation of the type specimen of Diaporthe nivosa revealed that it is a Melanconis sp., having a well-developed ectostromata and ascospores characteristic of that genus, thus $D$. nivosa is not similar with $D$. alnea.
Type material of Diaporthe nivosa examined: USA, Michigan, Isle Royale, Lake Superior, on dead wood of Alnus sp., July 1889, E.W.D. Holway, Ellis \& Everhart, North American Fungi Second Series 2535 (BPI 616604, lectotype designated here; MBT178535).

Diaporthe bicincta (Cooke \& Peck) Sacc., Syll. fung. (Abellini) 1: 622 (1882). Fig. 7a-c

Basionym. Valsa bicincta Cooke \& Peck, in Peck, Ann. Rep. N.Y. St. Mus. nat. Hist. 29: 64 (1878) [1876]

Pycnidia on alfalfa twigs on WA $200-300 \mu \mathrm{m}$ diam, globose, embedded in tissue, erumpent at maturity, welldeveloped, black stroma with a slightly elongated, 50$150 \mu \mathrm{m}$ long necks, often with off-white, conidial cirrus extruding from ostiole; walls parenchymatous, consisting of 3-4 layers of medium brown textura angularis. Conidiophores 7-12×1-2 $\mu \mathrm{m}$, hyaline, smooth, unbranched, ampulliform, cylindrical to sub-cylindrical. Conidiogenous cells $0.5-1 \mu \mathrm{m}$ diam, phialidic, cylindrical, terminal, slightly tapering towards apex. Paraphyses $80-100 \times 1-2 \mu \mathrm{m}$, hyaline, smooth, unbranched, elongated with acute apex. Alpha conidia 9-12 $\times 2-3.5 \mu \mathrm{m}(\overline{\mathrm{x} S D}=10 \pm 1 \times 3 \pm 0.3, n=30)$, abundant on alfalfa twigs, aseptate, hyaline, smooth, ovate to ellipsoidal, biguttulate or multiguttulate, base subtruncate. Beta conidia not observed.

Cultural characteristics: In dark at $25^{\circ} \mathrm{C}$ for $1 \mathrm{wk}$, colonies on PDA moderate growth rate, $3.8 \pm 0.2 \mathrm{~mm} /$ day $(n=8)$, white, aerial mycelium turning to grey at edges of plate, reverse white in centre; stroma produced in 1 wk old culture with abundant conidia.

Host range: On Juglans cinerea and Juglans sp. (Juglandaceae)

Geographic distribution: Canada (Ontario); USA (Iowa, New York, Pennsylvania, Tennessee).

Type material : USA, New York, Greenbush, on branch of Juglans cinerea, (NYS F 468, holotype); Tennessee, Great Smoky Mts National Park, dead wood of Juglans sp., 8 May 2006, L. Vasilyeva (BPI 878472, epitype designated here, ex-epitype culture DP0659=CBS 121004; MBT178536).

Additional material examined: CANADA, Ontario, Granton, on dead branches of Juglans sp., July 1898, J. Dearness (BPI 615762, 615766); USA, Iowa, Decorah, on dead branches of Juglans sp., June 1892, E.W.D. Holway (BPI 615761, BPI 615765); Pennsylvania, Bethlehem, on twigs of Juglans cinerea, 9 June 1922, C.L. Shear 4043, det. F. Petrak (BPI 615764).

Notes: Diaporthe bicincta has long paraphyses and larger conidia $(9-12 \times 2-3.5 \mu \mathrm{m})$ than D. juglandina on Juglans in Europe. The isolate CBS 121004 was deposited as D. juglandina (Gomes et al. 2013); however, this isolate was originally from the USA (Tennessee) and is here confirmed as D. bicincta based on a morphological comparison with the type and non-type specimens. 
Diaporthe celastrina Ellis \& Barthol., J. Mycol. 8: 173 (1902). Fig. 7d-f

Pycnidia on host and alfalfa twigs on WA $200-300 \mu \mathrm{m}$ diam, globose, embedded in tissue, erumpent at maturity, well developed, black stroma with a 50-150 $\mu \mathrm{m}$ long necks, often with an off-white, conidial cirrus extruding from ostiole; walls parenchymatous, consisting of 3-4 layers of medium brown textura angularis. Conidiophores $7-21 \times 1-2 \mu \mathrm{m}$, hyaline, smooth, unbranched, ampulliform, cylindrical. Conidiogenous cells $0.5-1 \mu \mathrm{m}$ diam, phialidic, cylindrical, terminal, slightly tapering towards apex. Paraphyses absent. Alpha conidia 9-12 $\times 2-3.5 \mu \mathrm{m}(\overline{\mathrm{x}} \pm \mathrm{SD}=10 \pm 0.8 \times 2.7 \pm 0.3$, $n=30$ ) abundant on alfalfa twigs, aseptate, hyaline, smooth, ellipsoidal, biguttulate, multiguttulate, or eguttulate, base subtruncate. Beta conidia not observed.

Cultural characteristics: In dark at $25^{\circ} \mathrm{C}$ for $1 \mathrm{wk}$, colonies on PDA fast growing, $5.8 \pm 0.2 \mathrm{~mm} /$ day $(n=8)$, white aerial mycelium, reverse white in centre; stroma produced in $1 \mathrm{wk}$ old culture.

Host range: On Celastrus scandens (Celastraceae).

Geographic distribution: USA (KS, VA).

Type materialUSA, Kansas, Clyde, Celastrus scandens, 18 May 1901, E. Bartholomew 2856 (BPI 615293, holotype). USA, on Celastrus scandens, September 1927, L.E. Wehmeyer (BPI 892915, epitype designated here, ex-epitype culture CBS 139.27; MBT178537).

Additional material examined USA, Virginia, Blacksburg, on Celastrus scandens. 13 October 1936, C.L. Shear (BPI 615294).

Notes: Diaporthe celastrina was originally described from Celastrus scandens in the USA (Kansas) and the epitype designated here is collected from the USA on the same host and also identified by L.E. Wehmeyer. The host Celastrus scandens (American Bittersweet, Celastraceae) is native to central and northeastern North America.

Diaporthe helicis Niessl, Verh. Naturforsch. Ver., Brünn 16: 50 (1876). Fig. $7 \mathrm{~g}-\mathrm{i}$

[=Diaporthe nitschkei J. Kunze, Fungi Selecti Exs. 124. (1877), nom. nud.]

Pycnidia on host and alfalfa twigs on WA $200-300 \mu \mathrm{m}$ diam, globose, embedded in tissue, erumpent at maturity, well developed, black stroma with a black, 50-150 $\mu \mathrm{m}$ long neck, often with an off white, conidial cirrus extruding from ostiole; walls parenchymatous, consisting of 3-4 layers of medium brown textura angularis. Conidiophores (6-) 8-15 (16.5) $\times 1-$ $2 \mu \mathrm{m}$, hyaline, smooth, unbranched, ampulliform, cylindrical to clavate. Conidiogenous cells $0.5-1 \mu \mathrm{m}$ diam, phialidic, cylindrical, terminal, tapering slightly towards apex. Paraphyses absent. Alpha conidia (5.5-) 6-8 (9.5) $\times 2.5-$ $3.5 \mu \mathrm{m}(\overline{\mathrm{x}} \pm \mathrm{SD}=7 \pm 0.5 \times 3 \pm 0.2, n=30)$, abundant on alfalfa twigs, aseptate, hyaline, smooth, cylindrical to ellipsoidal, biguttulate or multiguttulate, base subtruncate. Beta conidia not observed.
Cultural characteristics: In dark at $25^{\circ} \mathrm{C}$ for $1 \mathrm{wk}$, colonies on PDA fast growing, $5.6 \pm 0.2 \mathrm{~mm} /$ day $(n=8)$, white, aerial mycelium turning to grey, reverse white, turning to grey in centre; stroma produced in $1 \mathrm{wk}$ old culture with abundant conidia.

Host range: On vines and leaves of Hedera helix (Araliaceae)

Geographic distribution: Europe (France, Germany)

Type material: GERMANY, Saxony, Islebiam, on vines of Hedera helix, June 1875, J. Kunze (bound collection in BPI Joannes Kunze, Fungi Selecti Exsiccati 124, lectotype designated here; MBT178538, isolectotypes BPI 1108439; BPI 1108445); FRANCE, Veronnes, on vines of Hedera helix, 10 March 2011, A. Gardiennet (BPI 892919, epitype designated here, ex-epitype culture AR5211=CBS; MBT178539).

Notes: When Niessl (1876) described Diaporthe helicis, he referred to the J. Kunze specimen that was distributed as J. Kunze, Fungi Sel. Exsiccati 124 labeled Diaporthe nitschkei. Although that exsiccati number was issued in 1875, the label does not include a description and thus that name was not published. The name $D$. helicis published 1 year later is typified by that same exsiccati number.

Observations of the type specimens and additional material from Hedera confirmed that the fresh collection from France is $D$. helicis and belongs in the same species complex as does D. pulla described below. A comparison of representatives of $D$. helicis and D. pulla based on eight gene alignments and combined analysis revealed genetic differences suggesting that these two species are distinct.

The third species on Hedera, D. hederae, was described from the UK. Observations of a recent collection from Hedera in the UK confirmed that it is morphologically differ from $D$. helicis and D. pulla. The asexual morph produced by the isolate (M1078, in SMML culture collection, specimen BPI892914), from the UK has longer conidiophores (20$45 \times 2-2.4 \mu \mathrm{m})$ and the paraphyses are abundant, while D. helicis and D. pulla have shorter conidiophores $(8-15 \times$ 1-2 $\mu \mathrm{m}$ ) and paraphyses are absent. The ITS (KM111543) sequence similarity of the above referenced isolate from the UK confirmed that $D$. hederae can be a synonym of $D$. rudis (see Udayanga et al. (2014) for description and illustration).

Type material of Diaporthe hederae examine UK, Boxhill, on vines of Hedera helix, July 1930, E.W. Mason Detr. L.E. Wehmeyer (BPI 1108438).

Diaporthe neilliae Peck, Ann. Rep. N.Y. St. Mus. nat. Hist. 39: 52 (1887) [1886]. Fig. 8a-d

Perithecia on dead twigs, 200-300 $\mu \mathrm{m}$ diam, black, globose to conical, scattered irregularly, immersed in host tissue with elongated, 300-400 $\mu \mathrm{m}$ long necks protruding through substrata. Asci $36-50 \mu \mathrm{m} \times 7-10 \mu \mathrm{m}(\overline{\mathrm{x}} \pm \mathrm{SD}=45 \pm 5 \times 8.5 \pm 0.7$, $n=30$ ), unitunicate, 8 -spored, sessile, elongate to clavate. Ascospores (11-)12-13.5(-14.5) $\times 3.5-4 \mu \mathrm{m}(\overline{\mathrm{x}} \pm \mathrm{SD}=13 \pm$ $0.8 \times 3.8 \pm 0.3, n=30$ ), hyaline, two-celled, often 4-guttulate, 


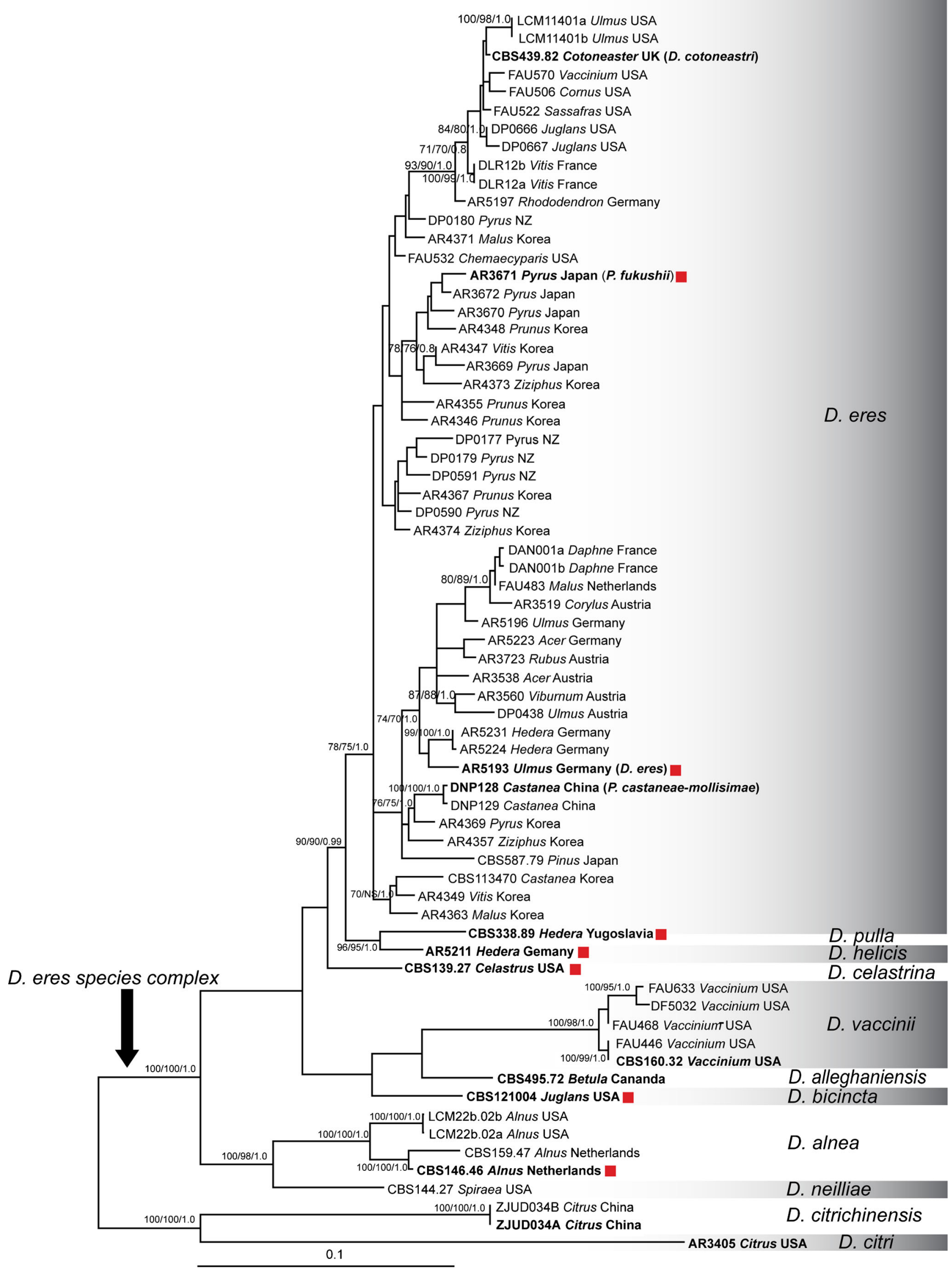


Fig. 3 The RAxML phylogram based on combined alignment of 7 genes (ACT, Apn2, CAL, EF1- $\alpha$, HIS, FG1093 and TUB) of Diaporthe eres species complex. The ML, MP bootstrap values $\geq 70 \%$, bayesian $\mathrm{PP} \geq$ 0.75 are indicated above the branches. The tree is rooted with Diaporthe citri (AR3405) and D. citrichinensis (ZJUD034A, B). Ex-type and exepitype cultures are in bold. Epitypes and neotypes designated in this study are indicated with a red squares

with larger guttules at centre and smaller one at ends, elongated to elliptical.

Cultural characteristics: In dark at $25{ }^{\circ} \mathrm{C}$ for $1 \mathrm{wk}$, colonies on PDA slow growing, $2.6 \pm 0.2 \mathrm{~mm} /$ day $(n=8)$, white, aerial mycelium, reverse white, turning to grey in centre; no conidia produced.

Host range: On Physocarpus opulifolius (Rosaceae).

Geographic distribution: USA (New York).

Type material: USA, New York, West Albany, on stems of Physocarpus opulifolius, C.H. Peck (NYS, holotype not examined, BPI 616581, isotype observed).

Additional material examined USA, on Spiraea sp., September 1927, L.E. Wehmeyer (BPI 892921, CBS 144.27).

Notes: Diaporthe neilliae is known only from the host species Physocarpus opulifolius; however, this host has been placed in various genera and has been reported as being on Neillia opulifolia, Opulaster opulifolus and Spiraea opulifolia, all names for the same species. This rosaceous host is native to North America, thus the isolate identified by L.E. Wehmeyer is used to represent this taxon; however, due to lack of information about its origin, it is not designated as the epitype.

Diaporthe pulla Nitschke, Pyrenomycetes Germanici 2: 249 (1870) Fig. 8e-g

=Phoma pulla Sacc., Michelia 2: 96 (1880)

EPhomopsis pulla (Sacc.) Traverso, Fl. ital. crypt., Pyrenomycetae (Florence) 2: 244 (1906)

Pycnidia on host and alfalfa twigs on WA 200-300 $\mu \mathrm{m}$ diam, globose, embedded in tissue, erumpent at maturity, well developed, black stromata, 50-300 $\mu \mathrm{m}$ long necks, often with bright yellow, conidial cirrus extruding from ostiole, walls parenchymatous, consisting of 3-4 layers of medium brown textura angularis. Conidiophores (10-) 12-20 (-25) $\times 1-$ $2 \mu \mathrm{m}$, hyaline, smooth, unbranched, ampulliform, cylindrical to clavate. Conidiogenous cells $0.5-1 \mu \mathrm{m}$ diam, phialidic, cylindrical, terminal, slightly tapering towards the apex. Paraphyses absent. Alpha conidia (6-) 6.5-7.5 (8) $\times(2-) 2.5-$ $3.5(-4) \mu \mathrm{m}(\overline{\mathrm{x}} \pm \mathrm{SD}=7 \pm 0.5 \times 3 \pm 0.5, n=30)$, abundant on alfalfa twigs, aseptate, hyaline, smooth, cylindrical to ellipsoidal, biguttulate or multi-guttulate, base subtruncate. Beta conidia not observed.

Cultural characteristics: In dark at $25{ }^{\circ} \mathrm{C}$ for $1 \mathrm{wk}$, colonies on PDA fast growing, $5.6 \pm 0.2 \mathrm{~mm} /$ day $(n=8)$, white aerial mycelium, reverse white, turning to grey in centre; black stromata produced in 1 wk with abundant conidia.
Host range: On dead and dying vines and leaves of Hedera helix (Araliaceae).

Geographic distribution: Europe (Czech Republic, France, Germany, Italy, Serbia)

Type material: GERMANY, on vines of Hedera helix, (Fries Scleromyceti Sueciae No. 307 (BPI Sbarbaro Collection, Bound, Centuries III (part) to V. in BPI as Sphaeria spiculosa, lectotype designated here; MBT178540); SERBIA, Belgrade, on vines of Hedera helix, July 1989, M. MuntanolaCvetkovic (BPI 892920, epitype designated here, ex-epitype culture, CBS 338.89; MBT178541).

Additional material examined: CZECH REPUBLIC (as Czechoslovakia), Maehren, Sternberg, in garden, stems of Hedera helix, October 1934, J. Piskor (BPI 801639); GERMANY, Schmilka, on stems of Hedera helix, September 1903, W. Krieger (BPI 1108429); Hesse, Oestrich, on stems of Hedera sp., L. Fuckel (BPI 1108479); ITALY, Castel Gandolfo, Rome, on stems of Hedera helix, July 1904, D. Saccardo (BPI 1108428).

Notes: Diaporthe pulla is distinguished from D. helicis based primarily on molecular phylogenetic differences. The combined alignment of eight genes that includes the two isolates from Hedera as well as the single gene analysis support the distinction of $D$. pulla from $D$. helicis. The other isolates from Hedera in Europe were identified as D. eres and D. rudis. A number of specimens are listed by Nitschke (1870) under the description of Diaporthe pulla. The specimens selected here as lectotype was among them and is not the type of Sphaeria spiculosa Batsch.

Diaporthe vaccinii Shear, United States Department of Agriculture Technical Bulletin 258: 7(1931)

$=$ Phomopsis vaccinii Shear, N.E. Stevens \& H.F. Bain, United States Department of Agriculture Technical Bulletin 258:7 (1931)

For description and illustrations, see Farr et al. (2002).

Host range: Vaccinium corymbosum, V. macrocarpon, $V$. oxycoccous (Ericaceae) (including the host association confirmed with molecular data in Lombard et al. 2014).

Geographic distribution: Latvia, Lithuania, Netherlands and USA

Type material examined: USA, Oregon, Clatsop, on Vaccinium macrocarpon, H.F. Bain, 1924 (BPI 617410, holotype).

Additional material examinedUSA, Massachusetts, on Vaccinium macrocarpon, C.L. Shear (authentic culture CBS 160.32); Oregon, Seaside, Vaccinium macrocarpon, 1923, H.F. Bain, (BPI 617405), ibid, 2 September 1924, C.L. Shear (BPI 617411); Oregon, Carnahan, Vaccinium macrocarpon, 20 September 1924, H.F. Bain, det. C.L. Shear (BPI 617406); Oregon, Intercepted Seattle Washington \#009527, Vaccinium macrocarpon, 3 May 1972, coll. W.H. Taussig, det. F.G. Pollack (BPI 617407); Oregon, Seaside, Vaccinium macrocarpon, 1923, H.F. Bain (BPI 617408); Unknown, fruit 
a

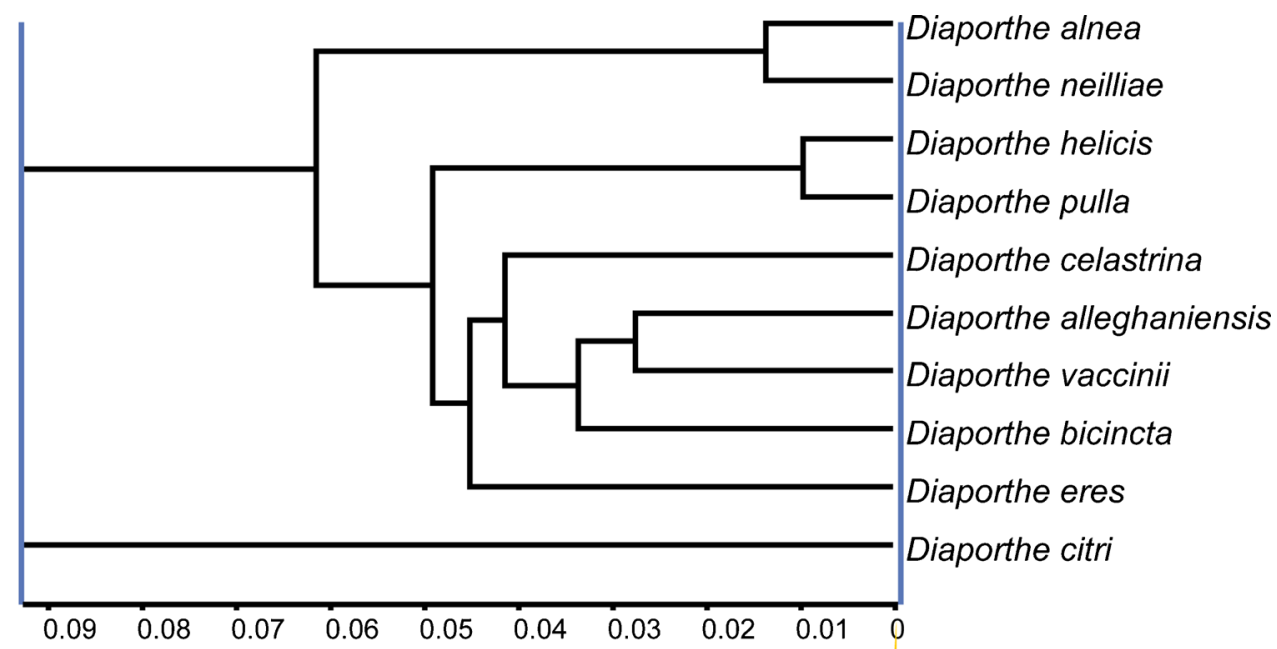

b

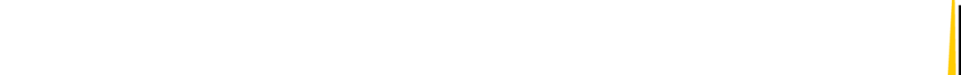

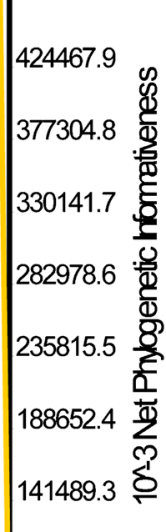

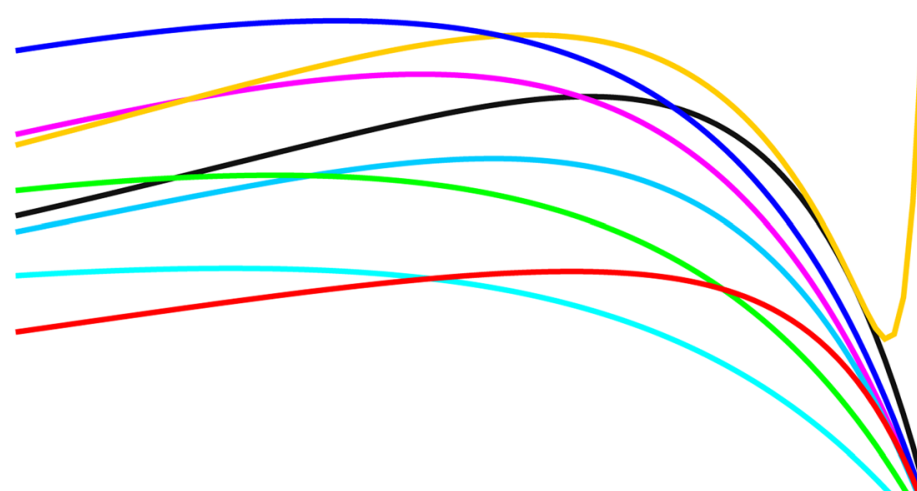

94326.2

47163.1

C

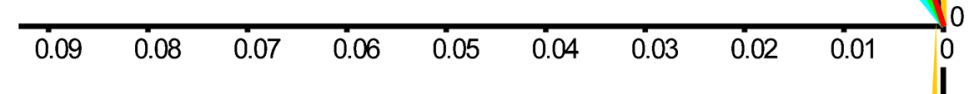

1

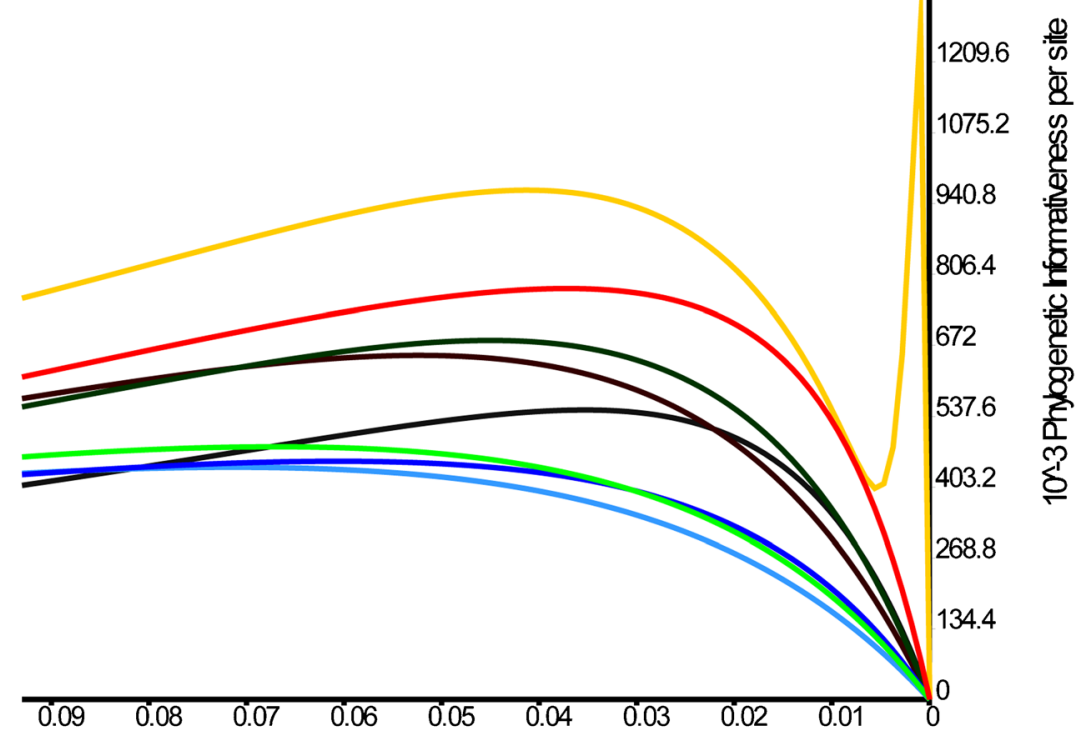

d

ACT

TUB

Apn2

EF1- $\alpha$

FG1093

HIS

CAL

ITS 
4 Fig. 4 Profiles of phylogenetic informativeness for the 10 cryptic species compared within $D$. eres species complex (based on types, epitypes or taxonomically authenticated isolates) and 8 genes included in the study. a) Ultrametric tree generated from the combined analysis of Apn2, ACT, ITS, EF1- $\alpha$, TUB, CAL, FG1093 and HIS genes b) Net Phylogenetic informativeness c) Phylogenetic informativeness per site. d) key

of Vaccinium macrocarpon, 1 March 1929, H.F. Bain (BPI 617409).

Notes: The type specimen of Diaporthe vaccinii was examined but no useful structures remain as had been noted previously by Wehmeyer (1933) and Farr et al. (2002). The authentic specimen listed in Farr et al. (2002) serves here as the reference material including sequences used in that study. Additional authentic material examined included the asexual morph with pycnidial structures and alpha conidia. Diaporthe vaccinii is known to cause twig blight and fruit rot of Vaccinium species and is primarily reported from the USA and it is reported on Vaccinium in Europe along with several other common taxa including D. eres (Lombard et al. 2014). However, this is one of relatively host specific pathogens within Diaporthe infecting on Vaccinium spp.

\section{Discussion}

Fungi are excellent models for studying eukaryotic evolution with many examples of highly diverse species complexes with multiple recently diverged sibling species (Dettman et al. 2003b, 2006; Kohn 2005; Pringle et al. 2005; Giraud et al. 2008). The genus Diaporthe is composed of species varying from relatively host-specific to species with broad host ranges. For instance D. alnea (on Alnus spp.), D. citri (on Citrus spp.), D. vaccinii (on Vaccinium spp.) and D. ampelina (formerly known as Phomopsis viticola on Vitis spp.) are known to be relatively host specific species, are often pathogenic, and show less infraspecific variability (Udayanga et al. 2014). The majority of the host-specific species are generally pathogens causing mild to serious diseases on their respective host plants. The occurrence of these host-specific pathogens supports the hypothesis of host switching and specialization in the speciation within diaporthalean genera (Sogonov et al. 2008; Mejia et al. 2008, 2011; Crous et al. 2012; Voglmayr et al. 2012; Walker et al. 2014). In contrast, species occurring on a wide range of hosts are mostly opportunistic pathogens or secondary invaders on saprobic host substrata. These species often show high genetic diversity and are sometimes regarded as species complexes (Gomes et al. 2013). Udayanga et al. (2014) recognised D. foeniculina and D. rudis as species occurring on an extensive range of hosts similar to $D$. eres as resolved in this study.
It is essential to define the generic type species Diaporthe eres for a meaningful phylogenetic reappraisal of Diaporthe, as well as to reveal its biology, ecology and host associations (Udayanga et al. 2011; Gomes et al. 2013; Rossman et al. 2014). Diaporthe eres has been reported as a weak to moderate pathogen of woody plants. Kaliterna et al. (2012) reported the association of $D$. eres with grapevine trunk disease in Croatia having moderate pathogenicity. They suggest that this plurivorous species could play an important role in the aetiology of grapevine trunk disease. Baumgartner et al. (2013) characterised the isolates of Diaporthe from North American vineyards and recognised the wide occurrence of $D$. eres in their collection. Interestingly, they recovered both ITS types of Diaporthe eres, one of which was named Phomopsis fukushii because of the high similarity with authentic isolates from Japan included in their analysis. However, they did not notice any morphological variability or differences in virulence and pathogenicity within the two groups. The weak pathogenic $D$. eres has been widely reported associated with ericaceous, rosaceous fruit trees and grapevines from Asia, Europe and USA (Kanematsu et al. 1999, 2000, 2007; Kaliterna et al. 2012; Lombard et al. 2014). Additionally Phomopsis sp. 6, reported from South Africa (van Niekerk et al. 2005), was confirmed as D. eres based on the sequence comparison, which also supports the association of this species as a weak pathogen or opportunistic saprobe of grape in different geographic regions. Gomes et al. (2013), observed an unresolved sub-clade, which they referred to as the Diaporthe nobilis species complex, represented by CBS 587.79, CBS 113470 and some of the isolates used in our analysis. Many of the isolates in that clade clustered within Diaporthe eres based on the application of GCPSR in our analysis except for CBS 338.89, which is identified herein as D. pulla. We confirm that this poorly supported nonmonophyletic grouping can be observed when ITS sequences are included in the combined analysis. Therefore, the recognition of the Diaporthe nobilis species complex (sensu Gomes) is redundant. As large numbers of sequences from Diaporthe species have accumulated, subsequent rigorous analyses have shown that the interpretation of phylogenetic trees at species level is subject to much confusion, especially in taxa associated with broad host ranges (Udayanga et al. 2014). These issues are not only significant in biodiversity and evolutionary contexts, but also in situations in which the accurate identification of plant pathogenic species is required for quarantine or other purposes.

The nuclear ribosomal internal transcribed spacer (ITS) region has been proposed as the standard fungal barcode (Schoch et al. 2012) and is also being used for sequencebased species delimitation in environmental surveys of fungi (Horton and Bruns 2001; Begerow et al. 2010; Peršoh 2013; Schoch et al. 2014). For a majority of groups of fungi, ITS is the predominantly available sequence in public databases 

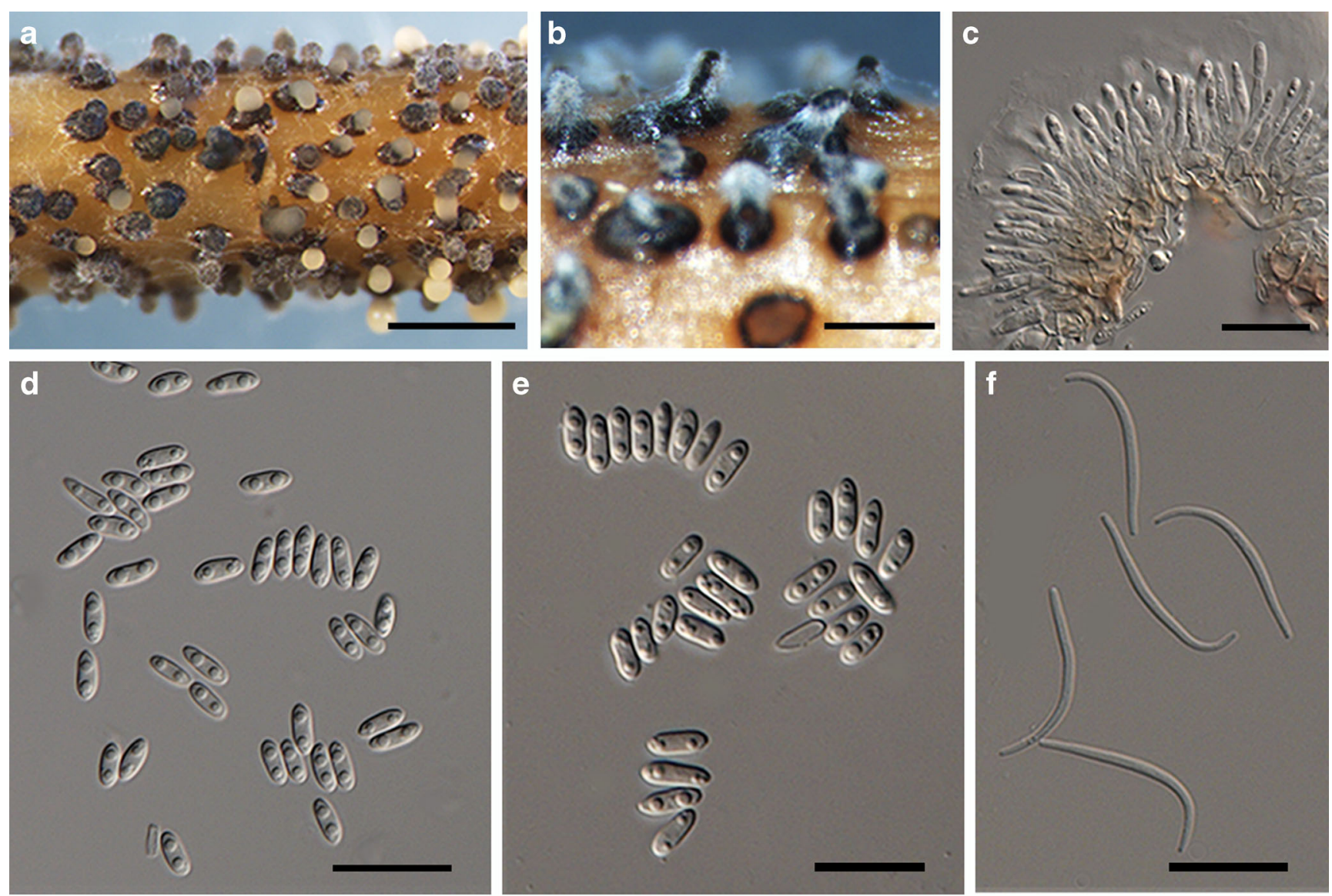

e

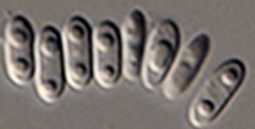
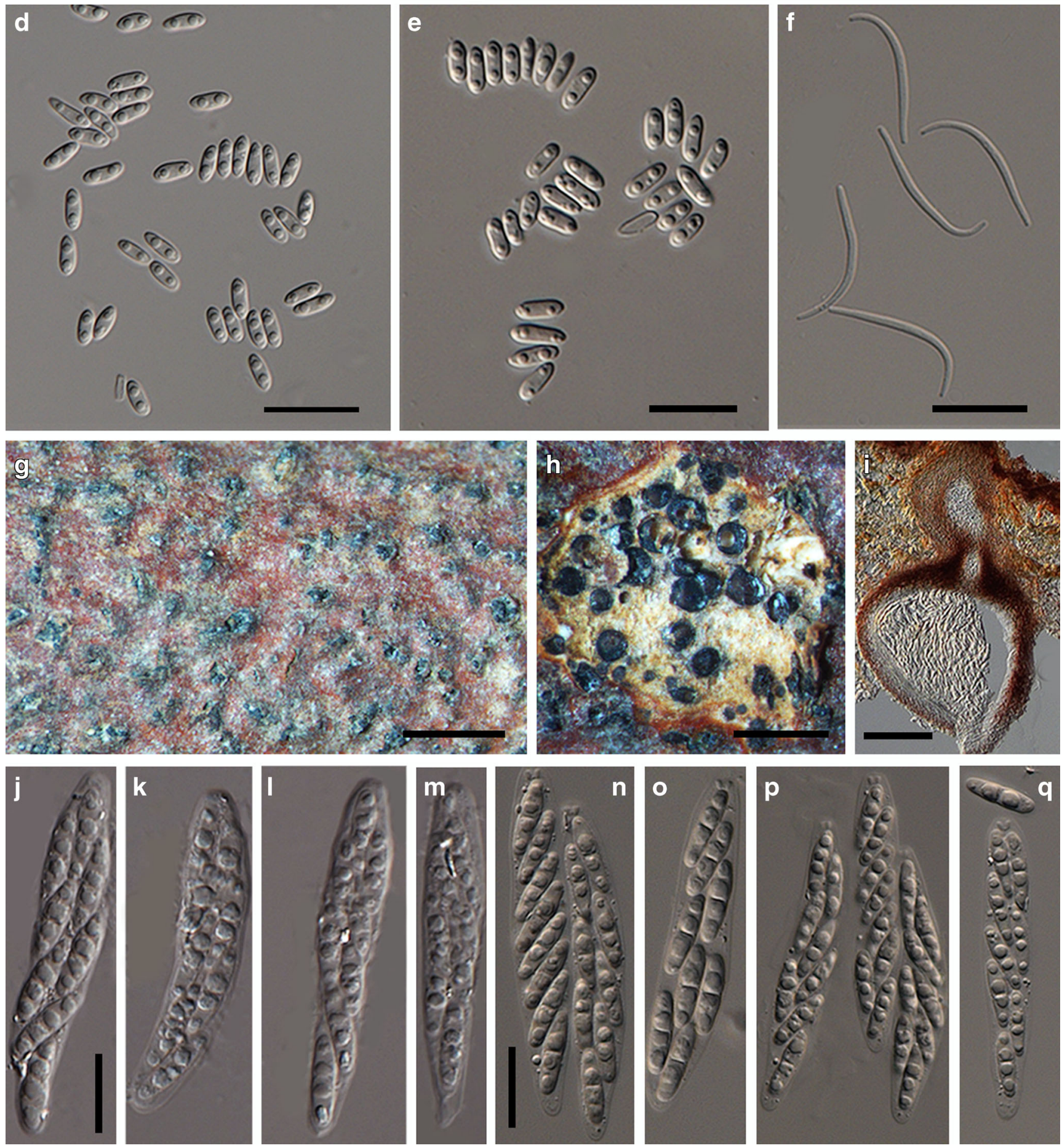

Springer 
4 Fig. 5 Morphology of Diaporthe eres a. Pycnidia on alfalfa stem on WA b. pycnidial necks protruding on alfalfa stem c. conidiophores d, e. $\alpha$ conidia $\mathbf{f}$. $\beta$-conidia g. Ectostroma on the dead twigs of Ulmus sp. $\mathbf{h}$. Perithecia i. Ascomata in section $\mathbf{j}-\mathbf{q}$. Asci and ascospores, Specimens: ae. AR5193 epitype culture g-m. B 700009145 lectotype specimen, n-q. epitype specimen (BPI 892912), Scale bars: $a=1000 \mu \mathrm{m}, \mathrm{b}=500 \mu \mathrm{m}, \mathrm{c}=$ $10 \mu \mathrm{m}, \mathrm{d}, \mathrm{e}=15 \mu \mathrm{m} \mathrm{f}=10 \mu \mathrm{m} \mathrm{g}=1000 \mu \mathrm{m}, \mathrm{h}=500 \mu \mathrm{m}, \mathrm{i}=100 \mu \mathrm{m}, \mathrm{J}-\mathrm{q}=$ $15 \mu \mathrm{m}$

(Nilsson et al. 2008, 2014; Kõljalg et al. 2013). Although ITS has been widely used in fungal systematics to delimit species and to understand evolutionary relationships, there are several known issues with the effectiveness of this region including the overestimating and underestimating fungal diversity (Schoch et al. 2012, 2014). On average the variability of the ITS1 exceeds that of ITS2, while the 5.8S fragment embedded between these two regions is highly conserved, and results of phylogenetic analysis of the complete sequence may differ from the analysis of the individual sub-loci (Nilsson et al. 2008; Monard et al. 2013).

The ITS region in the nuclear ribosomal cistron has undergone non-concerted patterns of evolution leading to paralogous ITS types within species in some important plant pathogenic genera (O’Donnell and Cigelnik 1997; Nilsson et al. 2008; Santos et al. 2010) and is considered by some authors to be uninformative due to the lack of interspecific variation or even misleading in some fungi (Crouch et al. 2009; Gaziz et al. 2011; Maharachchikumbura et al. 2012; Weir et al. 2012). Although complications resulting from ITS sequence data in Diaporthe have been recognised by several previous authors, they have not been thoroughly examined (Farr et al. 2002; Murali et al. 2006; Udayanga et al. 2014). In Santos et al. (2010) two ITS types tentatively named as A and $\mathrm{B}$ recovered from the isolates Di-C005/1-10 from Hydrangea in Portugal, derived from 10 individual sibling ascospores from the same perithecium were similar to the two large groups observed in our analysis (Fig. 1-a). However, our study reveals that the unidentified isolates Di-C005/1-10 belong to Diaporthe eres and cluster together as one species in the EF1- $\alpha$ phylogenetic tree. These differences were confined to the ITS1 region and are more extensive than the minor differences often noted among isolates of a single species. Sequence heterogeneity was not noted in the EF1- $\alpha$ and mating type genes for these same sibling isolates and the isolates were fully reproductively compatible (Santos et al. 2010). The same study further noted that both ITS types were not found in the genome of the same isolate, indicating that the different ITS types are independently segregated in meiotic events in this species. Comparison of the geographic origins and host associations of the isolates of $D$. eres used in this study with respect to the occurrence of two ITS types revealed that the different ITS sequences can be observed even within the same geographic region and the same host. We detected no evidence of sympatric patterns or host specialisation related to these ITS populations. The discordance of ITS versus other gene trees in combination with a lack of informative morphological characters to delineate taxa have lead to a confused taxonomic situation within this species complex. In this study, ITS analysis resulted in an unresolved phylogenetic tree without definitive bootstrap support at the internodes, highly discordant to the trees resulting from the other seven genes. Therefore ITS region was not used in the combined analysis. The conflict among gene trees can be reasonably explained by recombination among individuals within a species (Milgroom 1996; Geiser et al. 1998; Matute et al. 2006). However, in each of the species within $D$. eres complex, either the genealogical nondiscordance rule (Dettman et al. 2003a) or the genealogical concordance criterion has been fulfilled, revealing that there are significant barriers to gene flow among these species defined.

The seven gene analysis excluding the discordant ITS data resulted in a robust tree congruent with the EF1- $\alpha$ and other single genes. The species boundaries within the D. eres species complex were resolved in this study by application of criteria of phylogenetic species recognition (Taylor et al. 2000; Dettman et al. 2003a) revealing cryptic diversity that may be obscured by biological species recognition, morphology and discordance of genes. Several similar conclusions have been made in other fungal groups with cryptic species diversity, which also display little or no morphological variation (Dettman et al. 2003a, 2006; Walker et al. 2012; Weir et al. 2012; Manamgoda et al. 2013; Laurence et al. 2014).

The structure of the mating type genes and the association with Apn2 genes in Diaporthe were illustrated by Kanematsu et al. (2007). DNA-lyase genes have not traditionally been used as molecular markers in fungi; however, the association with mating type genes of fungi is known in relation to their structure. The Apn2 region has recently been used in conflicting genera like Colletotrichum (Crouch and Tomaso-Peterson 2012; Silva et al. 2012b; Doyle et al. 2013; Sharma et al. 2013) and the Apn2 and Apn2/MAT-IGS (intergenic spacer between 3' end of the DNA lyase and mating type locus MAT1-2) genetic markers recommended as a better marker in disentangling the $C$. gloeosporioides species complex (Silva et al. 2012a, b). Mating type genes of Diaporthe were amplified in several previous studies and utilised in phylogenetic analyses (Santos et al. 2010, 2011). Portions of the $\alpha-1$ box in MAT 1-1-1 gene (141 bp) and a portion of HMG domain of MAT 1-2-1 (229 bp) regions were shown to have less utility as phylogenetic markers than for screening mating types of isolates (Santos et al. 2010). The MAT phylogenetic trees were strongly correlated with EF1- $\alpha$ phylogenetic tree. However, MAT genes were less informative for more closely related species that could potentially be regarded as one biological species. At least some of taxa in species complexes might be regarded as reproductively compatible, but are distinct phylogenetic species. In our analyses of the available 

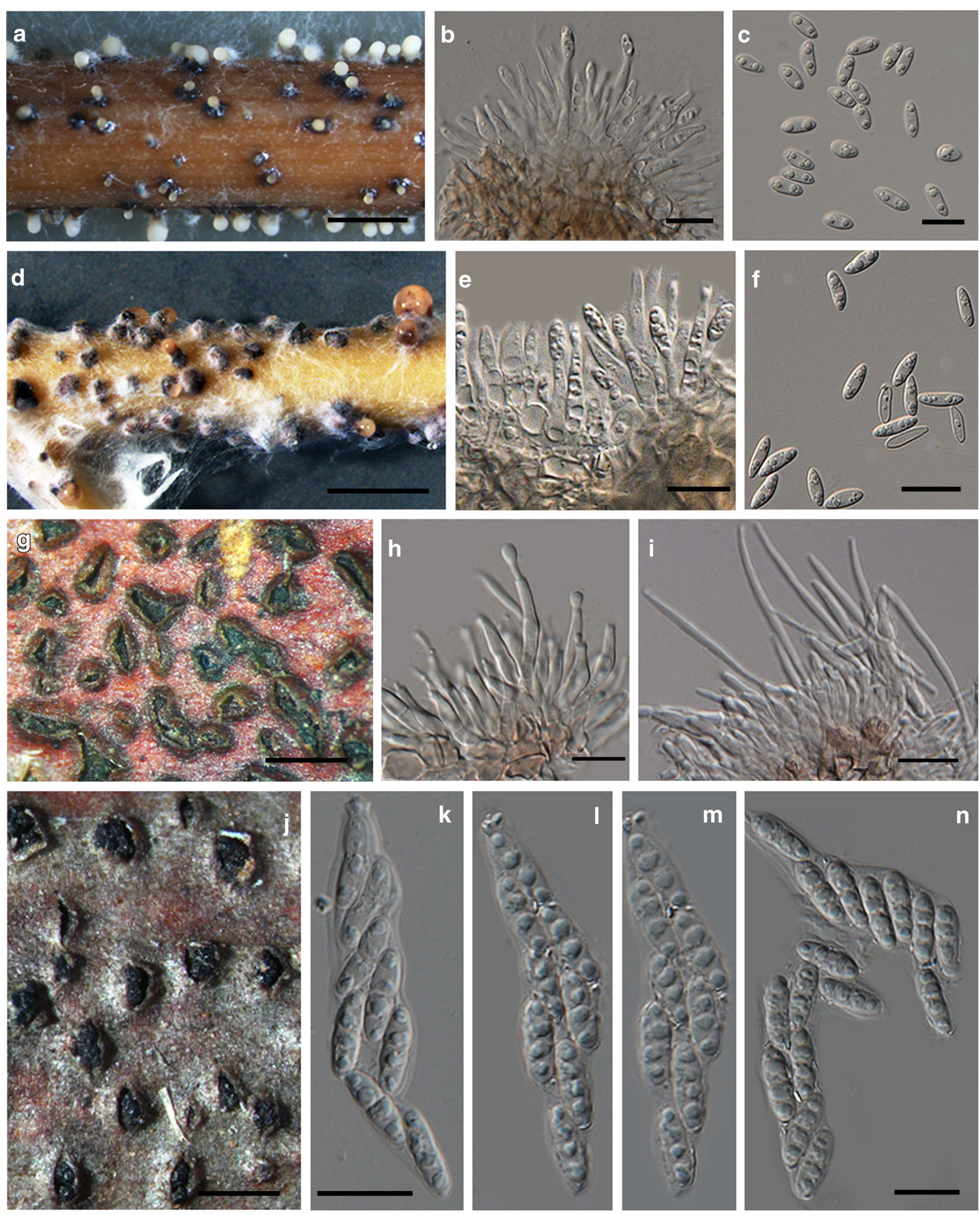

mating type sequences of the $D$. eres species complex with those generated by Santos et al. (2010) (as Diaporthe cotoneastri and D. vaccinii), species could not be distinguished based on MAT1-1-1 or MAT1-2-1 gene trees (trees 
4 Fig. 6 Morphology of Diaporthe alleghaniensis $(\mathrm{a}-\mathrm{c})$, D. alnea $(\mathrm{d}-\mathrm{n}) \mathbf{a}$. Pycnidia on alfalfa stem on WA, b. Conidiophores c. $\alpha$ - conidia d. Pycnidia on alfalfa stem e. conidiophores $\mathbf{f}$. $\alpha$-conidia $\mathbf{g}$. infected stem of Alnus sp. with ruptures on bark and pycnidia $\mathbf{h}$. $\alpha$ - conidiophores and conidiognous cells $\mathbf{i}$. $\beta$ - conidiophores and conidia $\mathbf{j}$. Ectostroma on twigs of Alnus sp. k-m. Asci n. Ascospores, Specimens: a-c. ex-type culture CBS 495.72, d-f. culture LCM22b.02a, g-h. lectotype specimen Fungi rhenani 1988 in FH, i-n. isolectotype specimen BPI 615718, Scale bars: $\mathrm{a}=800 \mu \mathrm{m}, \mathrm{b}, \mathrm{c}=10 \mu \mathrm{m}, \mathrm{d}=3000 \mu \mathrm{m}, \mathrm{e}, \mathrm{f}=12 \mu \mathrm{m}, \mathrm{g}=500 \mu \mathrm{m}, \mathrm{h}, \mathrm{i}=$ $12 \mu \mathrm{m}, \mathrm{j}=1000 \mu \mathrm{m}, \mathrm{k}-n=15 \mu \mathrm{m}$

not shown). However, in heterothallic species mating type genes may not always be appropriate as phylogenetic markers due to their absence in different strains. To our knowledge, this study is the first ever utility of Apn2 gene as a phylogenetic marker within the genus Diaporthe. The comparison of phylogenetic informativeness revealed that it is a competing marker for EF1- $\alpha$ and HIS genes. The Apn2 region has the advantage of being highly informative and bearing a shorter hypervariable intron region allowing a more accurate global alignment that is sometimes impossible with EF1- $\alpha$ in this genus.

The phylogenetic informativeness profiles generated based on PhyDesign were used to compare each locus with respect to the species hypothesis inferred based on the multi-gene phylogenetic analysis. Apn2, EF1- $\alpha$ and HIS genes showed the highest net phylogenetic informativeness, with EF1- $\alpha$ showing the highest informativeness per site. The phylogenetic informativeness per site is useful in comparing the relative power of genes regardless of gene length. These profiles are useful in determining the most informative genes for facilitating
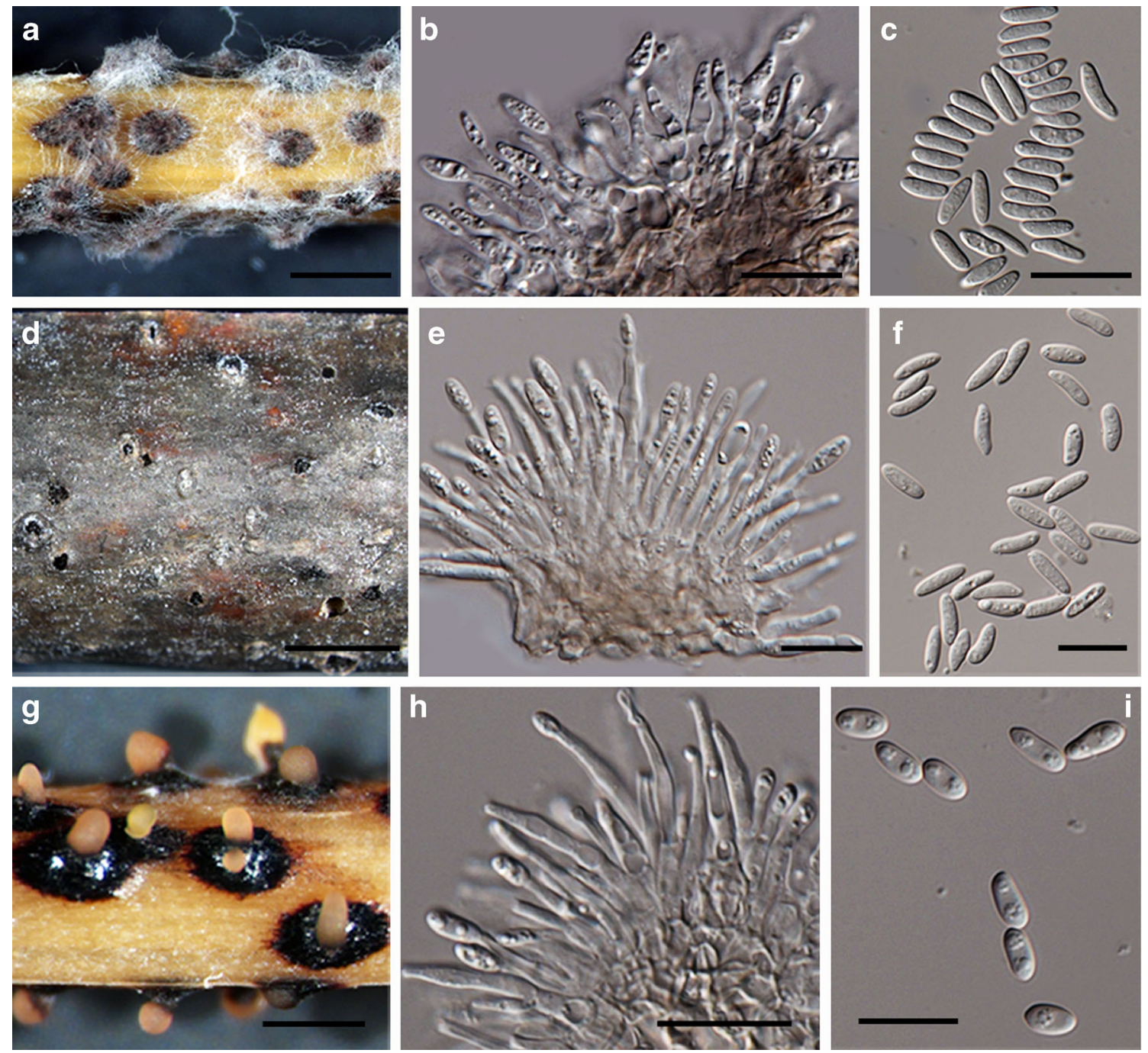

Fig. 7 Morphology of Diaporthe bicincta (a-c), D. celastrina (d-f), D. helicis ( $\mathrm{g}-\mathrm{i})$ a. Pycnidia on alfalfa stem on WA b. Conidiophores $\mathbf{c}$.

WA h. conidiophores i. $\alpha$-conidia. Specimens: a-c. ex-epitype culture CBS 121004, d-f. Holotype BPI 615293 g-i. ex-epitype culture (AR5211), Scale bars: $\mathrm{a}=1000 \mu \mathrm{m}, \mathrm{b}, \mathrm{c}=15 \mu \mathrm{m}, \mathrm{d}=2000 \mu \mathrm{m}, \mathrm{e}, \mathrm{f}$ $\alpha$-conidia Specien d. Surface view of infected stem of Celastrus scandens with pycnidia e. conidiophores $\mathbf{f}$. $\alpha$ - conidia g. Pycnidia on alfalfa stem on

$=12 \mu \mathrm{m}, \mathrm{g}=, 1000 \mu \mathrm{m}, \mathrm{h}, \mathrm{i}=10 \mu \mathrm{m}$ 

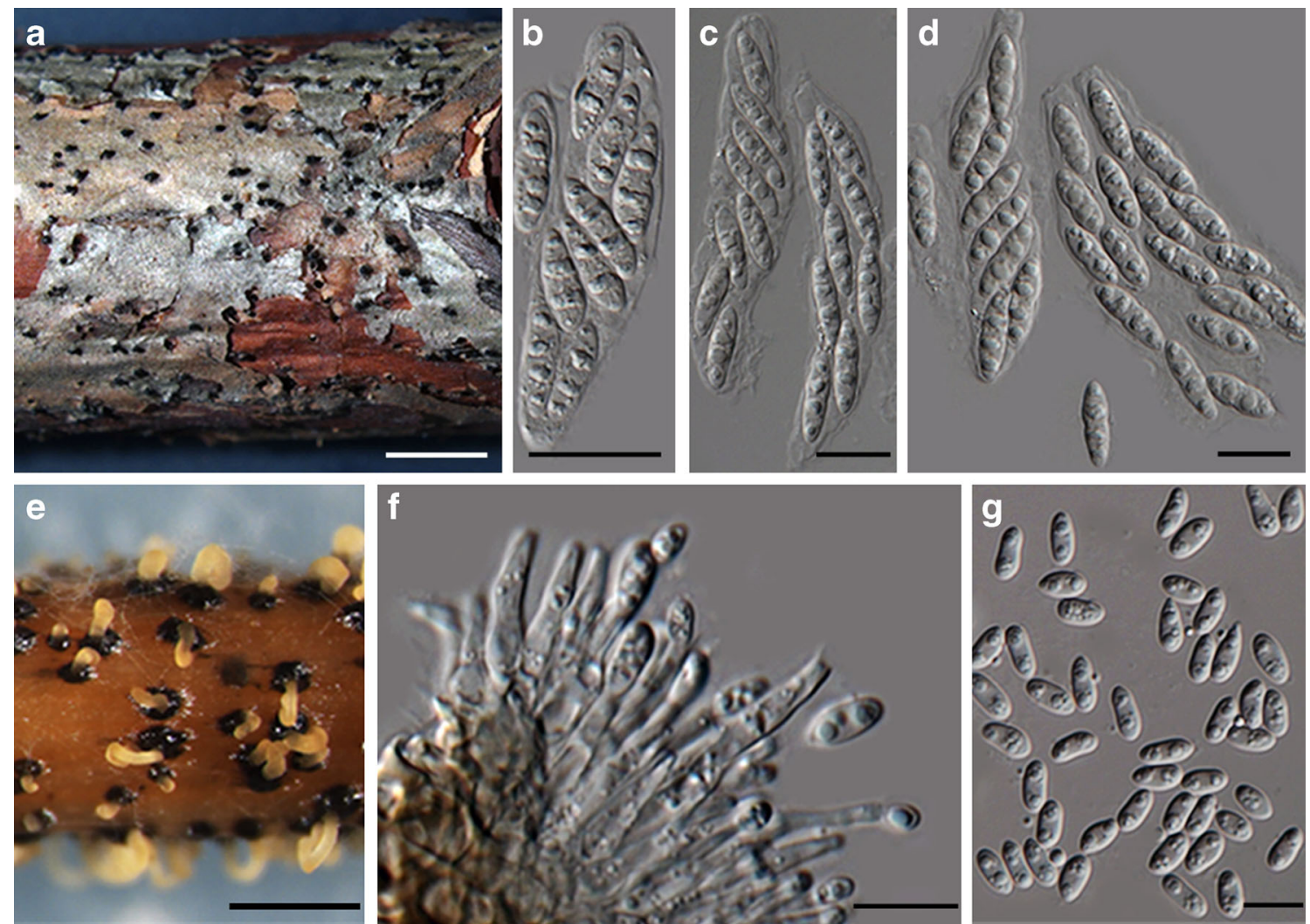

Fig. 8 Morphology of Diaporthe neilliae (a-d) and D. pulla (e-g) a. Ectostoma on dead stem of Physocarpus opulifolius b-c. Asci d. Asci and ascospores e. Pycnidia on alfalfa stem on WA f. conidiophores g. $\alpha$ -

conidia, Specimens: a-d. Holotype of D. neilliae BPI 616581, e-g. exepitype culture CBS 338.89, Scale bars: $a=2000 \mu \mathrm{m}, \mathrm{b}=15 \mu \mathrm{m}, \mathrm{c}, \mathrm{d}=$ $12 \mu \mathrm{m} \mathrm{e}=1800 \mu \mathrm{m}, \mathrm{f}=12 \mu \mathrm{m}, \mathrm{g}=8 \mu \mathrm{m}$

locus prioritisation and increasing the efficiency of sequencing for phylogenetic purposes (Townsend 2007). The relatively recent "phantom" spikes in EF1- $\alpha$ phylogenetic informativeness plots arise because the maximum likelihood estimate for the rate of a few sites has its peak at infinity, which has little biological meaning (http://phydesign.townsend.yale.edu/faq.html). The EF 1- $\alpha$ gene was used initially to provide an estimate of the species boundaries with six additional genes including ACT, Apn2, CAL, FG1093, HIS and TUB genes compared individually and in combinations. The approximately $300 \mathrm{bp}$ complete intron sequence of the translation elongation factor $1-\alpha$ has previously been recognised as a powerful marker within Diaporthe to define cryptic species (Castlebury et al. 2001; Santos et al. 2010; Udayanga et al. 2012a, b, 2014)

The infraspecific variability of the highly informative genes as well as the less informative genes is a factor to be considered in the large scale evolutionary reconstruction of the genus. However, it is important to increase sampling of each species from a wide range of hosts using additional genes to clarify the topological conflicts of single gene analyses. Novel species may be encountered in unexplored ecological niches in which these fungi occur as endophytes, pathogens or saprobes.

Acknowledgments This work was completed at the Systematic Mycology and Microbiology Laboratory (SMML), Agricultural Research Service, United States Department of Agriculture in Beltsville, MD, USA, under the direction of co-authors Castlebury and Rossman. Dhanushka Udayanga is grateful for the visiting studentship sponsored through the U.S. Forest Service International Programs by SMML. Field collections were generously shared with us by the following people without whom this study would not have been possible. We thank David Farr (USA), Alain Gardiennet (France) Sung Kee Hong (Korea), Feng Huang (China), Walter Jaklitsch (Austria), Wadia Kandula (New Zealand), Luis Mejia (Panama), Larignon Phillipe (France) and Rene Schumacher (Germany). In addition we appreciate the loan of specimens by the herbarium curators and managers of B, BPI and FH. KD Hyde thanks The Chinese Academy of Sciences, project number 2013T2S0030, for the award of Visiting Professorship for Senior International Scientists at Kunming Institute of Botany. Technical support for this project was provided by Tunesha Phipps whose assistance is greatly appreciated.

Open AccessThis article is distributed under the terms of the Creative Commons Attribution License which permits any use, distribution, and reproduction in any medium, provided the original author(s) and the source are credited. 


\section{References}

Anagnostakis SL (2007) Diaporthe eres (Phomopsis oblonga) as a pathogen of butternut (Juglans cinerea) in Connecticut. Plant Dis 91:1198

Arnold RH (1967) A canker and foliage disease of yellow birch: description of the causal fungus Diaporthe alleghaniensis sp.nov. and symptoms on the host. Can J Bot 45:783-801

Avise JC, Ball RM (1990) Principles of genealogical concordance in species concepts and biological taxonomy. Oxford University Press, Oxford

Barr ME (1978) The Diaporthales in North America with emphasis on Gnomonia and its segregates. Mycol Mem 7:1-232

Baumgartner K, Fujiyoshi PT, Travadon R, Castlebury LA, Wilcox WF, Rolshausen PE (2013) Characterization of species of Diaporthe from wood cankers of grape in eastern North American vineyards. Plant Dis 97:912-920

Begerow D, Nilsson H, Unterseher M, Maier W (2010) Current state and perspectives of fungal DNA barcoding and rapid identification procedures. Appl Microbiol Biot 87:99-108

Bickford D, Lohman DJ, Sodhi NS, Ng PKL, Meier R, Winker K, Ingram KK, Das I (2007) Cryptic species as a window on diversity and conservation. Trends Ecol Evol 22:148-155

Bischoff JF, Rehner SA, Humber RA (2009) A multilocus phylogeny of the Metarhizium anisopliae lineage. Mycologia 101:512-530

Brayford D (1990) Variation in Phomopsis isolates from Ulmus species in the British Isles and Italy. Mycol Res 94:691-697

Cai L, Giraud T, Zhang N, Begerow D, Cai GH, Shivas RG (2011) The evolution of species concepts and species recognition criteria in plant pathogenic fungi. Fungal Divers 50:121-133

Casieri L, Hofstetter V, Viret O, Gindro K (2009) Fungal communities living in the wood of different cultivars of young Vitis vinifera plants. Phytopathol Mediterr 48(1):73-83

Castlebury LA, Farr DF, Rossman AY (2001) Phylogenetic distinction of Phomopsis isolates from cucurbits. Inoculum 52:25

Castlebury LA, Farr DF, Rossman AY, Jaklitsch WJ (2003) Diaporthe angelicae comb. nov., a modern description and placement of Diaporthopsis in Diaporthe. Mycoscience 44:203-208

Cline ET, Farr DF (2006) Synopsis of fungi listed as regulated plant pests by the USDA animal and plant health inspection service: notes on nomenclature, disease, plant hosts, and geographic distribution. Online Plant Health Prog. doi:10.1094/PHP-2006-0505-01-DG

Crouch JA, Tomaso-Peterson M (2012) Anthracnose disease of centipedegrass turf caused by Colletotrichum eremochloa, a new fungal species closely related to Colletotrichum sublineola. Mycologia 104:108-1096

Crouch JA, Clarke BB, Hillman BI (2009) What is the value of ITS sequence data in Colletotrichum systematics and species diagnosis? A case study using the falcate-spored graminicolous Colletotrichum group. Mycologia 101:648-656

Crous PW, Gams W, Stalpers JA, Robert V, Stegehuis G (2004a) MycoBank: an online initiative to launch mycology into the 21st century. Stud Mycol 50:19-22

Crous PW, Groenewald JZ, Risede J-M, Hywel-Jones NL (2004b) Calonectria species and their Cylindrocladium anamorphs: species with sphaeropedunculate vesicles. Stud Mycol 50:415-430

Crous PW, Summerell BA, Alfenas AC, Edwards J, Pascoe IG, Porter IJ, Groenewald JZ (2012) Genera of diaporthalean coelomycetes associated with leaf spots of tree hosts. Persoonia 28:66-75

Crous PW, Giraldo A, Hawksworth DL, Robert V, Kirk PM, Guarri J, Robbertse B, Schoch CL, Damm U, Trakunyingcharoen T, Groenewald JZ (2014) The genera of fungi: fixing the application of type species of generic names. IMA Fungus 5:141-160

Damm U, Cannon PF, Liu F, Barreto RW, Guatimosim E, Crous PW (2013) The Colletotrichum orbiculare species complex: important pathogens of field crops and weeds. Fungal Divers 61:29-59
Dettman JR, Jacobson DJ, Taylor JW (2003a) A multilocus genealogical approach to phylogenetic species recognition in the model eukaryote Neurospora. Evolution 57:2703-2720

Dettman JR, Jacobson DJ, Turner E, Pringle A, Taylor JW (2003b) Reproductive isolation and phylogenetic divergence in Neurospora: comparing methods of species recognition in a model eukaryote. Evolution 57:2721-2741

Dettman JR, Jacobson DJ, Taylor JW (2006) Multilocus sequence data reveal extensive phylogenetic species diversity within the Neurospora discreta complex. Mycologia 98:436-446

Doyle VP, Oudemans P, Rehner SA, Litt A (2013) Habitat and host as useful indicators of lineage identity in Colletotrichum gloeosporioides s.l. from wild and agricultural landscapes in North America. PLoS ONE 8(5):e62394

Dupis JR, Roe AD, Fah S (2012) Multi-locus species delimitation in closely related animals and fungi: one marker is not enough. Mol Ecol 21:4422-4436

Farr DF, Castlebury LA, Rossman AY (2002) Morphological and molecular characterization of Phomopsis vaccinii and additional isolates of Phomopsis from blueberry and cranberry in the eastern United States. Mycologia 94:494-504

Fekete E, Irinyi L, Karaffa L, Árnyasi M, Asadollahi M (2012) Genetic diversity of a Botrytis cinerea cryptic species complex in Hungary. Microbiol Res 167:283-291

Garibaldi A, Bertetti D, Poli A, Gullino ML (2011) First report of black rot caused by Phomopsis cucurbitae on cantaloupe (Cucumis melo) in the piedmont region of northern Italy. Plant Dis 95:317-1317

Gaziz S, Rehner SA, Chaverri P (2011) Species delimitation in fungal endophyte diversity studies and its implications in ecological and biogeographic inferences. Mol Ecol 20:30013013

Geiser DM, Pitt JI, Taylor JW (1998) Cryptic speciation and recombination in the aflatoxin-producing fungus Aspergillus flavus. Proc Natl Acad Sci USA 95388-393.

Giraud T, Refregier G, de Vienne DM, Le Gac M, Hood ME (2008) Speciation in fungi. Fungal Genet Biol 45:791-802

Glass NL, Donaldson GC (1995) Development of primer sets designed for use with the PCR to amplify conserved genes from filamentous ascomycetes. Appl Environ Microb 61:1323-1330

Gomes RR, Glienke C, Videira SIR, Lombard L, Groenewald JZ, Crous PW (2013) Diaporthe: a genus of endophytic, saprobic and plant pathogenic fungi. Persoonia 31:1-41

Groenewald JZ, Nakashima C, Nishikawa J, Shin HD, Park JH, Jama AN, Groenewald M, Braun U, Crous PW (2013) Species concepts in Cercospora: spotting the weeds among the roses. Stud Mycol 75: 115-170

Gueidan C, Roux C, Lutzoni F (2007) Using a multigene analysis to assess generic delineation and character evolution in Verrucariaceae (Verrucariales, Ascomycota). Mycol Res 111:1147-1170

Hibbett DS, Taylor JW (2013) Fungal systematics: is a new age of enlightenment at hand? Nat Rev Microbiol 11:129-133

Horton TR, Bruns TD (2001) The molecular revolution in ectomycorrhizal ecology: peeking into the black-box. Mol Ecol 10:1855-1871

Huang F, Hou X, Dewdney MM, Fu Y, Chen GQ, Hyde KD, Li H (2013) Diaporthe species occurring on Citrus in China. Fungal Divers 61: 237-250

Huelsenbeck JP, Ronquist F (2001) MrBayes: Bayesian inference of phylogenetic trees. Bioinformatics 17:754-755

Hyde KD, Udayanga D, Manamgoda DS, Tedersoo L, Larsson E, Abarenkov K, Bertrand YJK, Oxelman B, Hartmann M, Kauserud H, Ryberg M, Kristiansson E, Nilsson RH (2013) Incorporating molecular data in fungal systematics: a guide for aspiring researchers. Curr Res Environ Appl Mycol 3:1-32

Index Fungorum (2014) http://www.indexfungorum.org/names/names. asp, retrieved on 01 March 2014. 
Kaliterna J, Milicevici T, Cvjetkovic B (2012) Grapevine trunk diseases associated with fungi from the Diaporthaceae family in Croatian vineyards. Arch Ind Hyg Toxicol 63:471-478

Kanematsu S, Kobayashi T, Kudo A, Ohtsu Y (1999) Conidial morphology, pathology and culture characteristics of Phomopsis isolates from Peach, Japanese pear and Apple in Japan. Annu Phytopath Soc Jpn 65:264-273

Kanematsu S, Minaka N, Kobayashi T, Kudo A, Ohtsu Y (2000) Molecular phylogenetic analysis of ribosomal DNA internal transcribed spacer regions and comparison of fertility in Phomopsis isolates from fruit trees. J Gen Plant Pathol 66:191-201

Kanematsu S, Adachi Y, Ito T (2007) Mating-type loci of heterothallic Diaporthe spp.: homologous genes are present in opposite matingtypes. Curr Genet 52:11-22

Katoh K, Standley DM (2013) MAFFT multiple sequence alignment software version 7: improvements in performance and usability. Mol Biol Evol 30:772-780

Kohn LM (2005) Mechanisms of fungal speciation. Annu Rev Phytopathol 43:279-308

Kõljalg U, Nilsson RH, Abarenkov K, Tedersoo L, Taylor AFS, Bahram $M$ et al (2013) Towards a unified paradigm for sequence-based identification of fungi. Mol Ecol 22:5271-5277

Kolomiets T, Mukhina Z, Matveeva T, Bogomaz D, Berner DK, Cavin CA, Castlebury LA (2009) First report of stem canker of Salsola tragus caused by Diaporthe eres in Russia. Plant Dis 93:110

Laurence MH, Summerell BA, Burgess LW, Liew EC (2014) Genealogical concordance phylogenetic species recognition in the Fusarium oxysporum species complex. Fungal Biol 118:374-384

Liu K, Warnow TJ, Holder MT, Nelesen S, Yu J, Stamatakis A, Linder RC (2012) SATé-II: Very fast and accurate simultaneous estimation of multiple sequence alignments and phylogenetic trees. Syst Biol 61:90-106

Lombard L, van Leeuwen G, Guarnaccia V, Polizzi G, van Rijswick P, Rosendahl K, Crous P (2014) Diaporthe species associated with Vaccinium in Europe. Phytopathologia Mediterranea. [S.1.], apr. 2014. ISSN 1593-2095. http://www.fupress.net/index.php/pm/ article/view/14034. doi:10.14601/Phytopathol_Mediterr 14034

Lopez-Giraldez F, Townsend JP (2011) PhyDesign: an online application for profiling phylogenetic informativeness. BMC Evol Biol 11:152

Maddison W P, Maddison DR (2011) Mesquite: a modular system for evolutionary analysis. Version $2.75 \mathrm{http}: / /$ mesquiteproject.org

Maharachchikumbura SS, Guo LD, Cai L, Chukeatirote E, Wu WP, Sun X, Hyde KD (2012) A multi-locus backbone tree for Pestalotiopsis, with a polyphasic characterization of 14 new species. Fungal Divers 56:95-129

Manamgoda DS, Udayanga D, Cai L, Chukeatirote E, Hyde KD (2013) Endophtic Colletotrichum associated with tropical grasses with a new species $C$. endophytica. Fungal Divers 61:107-115

Matute DR, McEwen JG, Puccia R, Montes BA, San-Blas G, Bagagli E, Taylor JW (2006) Cryptic speciation and recombination in the fungus Paracoccidioides brasiliensis as revealed by gene genealogies. Mol Biol Evol 23:65-73

Mejia LC, Castlebury L, Rossman AY, Sogonov MV, White JF (2008) Phylogenetic placement and taxonomic review of the genus Cryptosporella and its synonyms Ophiovalsa and Winterella. Mycol Res 112:23-35

Mejia LC, Castlebury LA, Rossman AY, Sogonov MV, White JF (2011) A systematic account of the genus Plagiostoma (Gnomoniaceae, Diaporthales) based on morphology, host associations and a fourgene phylogeny. Stud Mycol 68:211-235

Milgroom MG (1996) Recombination and the multilocus structure of fungal populations. Annu Rev Phytopathol 34:457-477

Miller MA, Pfeiffer W, Schwartz T (2010) Creating the CIPRES Science Gateway for inference of large phylogenetic trees. In: Proceedings of the Gateway Computing Environments Workshop (GCE), 14 Nov. 2010, New Orleans, Louisiana

Monard C, Gantner S, Stenlid J (2013) Utilizing ITS1 and ITS2 to study environmental fungal diversity using pyrosequencing. FEMS Microbiol Ecol 84:165-175

Murali TS, Suryanarayanan TS, Geeta R (2006) Endophytic Phomopsis species: host range and implications for diversity estimates. Can J Microbiol 52:673-680

Nilsson RH, Kristiansson E, Ryberg M, Hallenberg N, Larsson KH (2008) Intraspecific ITS variability in the kingdom Fungi as expressed in the international sequence databases and its implications for molecular species identification. Evol Bioinform 4:193201

Nilsson RH, Hyde KD, Pawłowska J, Ryberg M, Tedersoo L et al. (2014). Improving ITS sequence data for identification of plant pathogenic fungi. Fungal Divers. In Press, doi:10.1007/s13225-014-0291-8

Nitschke T (1870) Pyrenomycetes Germanici 2:245 Breslau. Eduard Trewendt, Germany

Nylander JAA (2004) MrModeltest v2. Program distributed by the author. Evolutionary biology centre. Uppsala University, Uppsala

O’Donnell K, Cigelnik E (1997) Two divergent intragenomic rDNA ITS2 types within a monophyletic lineage of the fungus Fusarium are nonorthologous. Mol Phylogenet Evol 7:103-116

O’Donnell K, Kistler HC, Tacke BK, Casper HC (2000) Gene genealogies reveal global phylogeographic structure and reproductive isolation among lineages of Fusarium graminearum, the fungus causing wheat scab. Proc Natl Acad Sci U S A 97:7905-7910

O’Donnell K, Ward TJ, Geiser DM, Kistler HC, Aoki T (2004) Genealogical concordance between the mating type locus and seven other nuclear genes supports formal recognition of nine phylogenetically distinct species within the Fusarium graminearum clade. Fungal Genet Biol 41:600-623

O’Donnell K, Rooney AP, Proctor RH, Brown DW, McCormick SP, Ward TJ, Frandsen RJN, Lysøe E, Rehner SA, Aoki T, Robert VARG, Crous PW, Groenewald JZ, Kang S, Geiser DM (2013) $R P B 1$ and $R P B 2$ phylogeny supports an early Cretaceous origin and a strongly supported clade comprising all agriculturally and medically important Fusaria. Fungal Genet Biol 52:20-31

Page RDM (1996) TREEVIEW: an application to display phylogenetic trees on personal computers. Comput Appl Biosci 12:357-358

Peršoh D (2013) Factors shaping community structure of endophytic fungi-evidence from the Pinus-Viscum-system. Fungal Divers 60: $55-69$

Pond SLK, Frost SDW, Muse SV (2005) HyPhy:hypothesis testing using phylogenies. Bioinformatics 21:676-679

Pringle A, Baker DM, Platt JL, Wares JP, Latge JP, Taylor JW (2005) Cryptic speciation in the cosmopolitan and clonal human pathogenic fungus Aspergillus fumigatus. Evolution 59:1886-1899

Quaedvlieg W, Binder M, Groenewald JZ, Summerell BA, Carnegie AJ, Burgess TI, Crous PW (2014) Introducing the consolidated species concept to resolve species in the Teratosphaeriaceae. Persoonia 33: $1-40$

Rambaut A, Drummond A (2008) Fig Tree: Tree figure drawing tool, version 1.2. 2. Institute of Evolutionary Biology, University of Edinburgh

Rehner SA, Uecker FA (1994) Nuclear ribosomal internal transcribed spacer phylogeny and host diversity in the coelomycete Phomopsis. Can J otany 72:166-167

Ronquist F, Huelsenbeck JP, van der Mark P (2005) MrBayes 3.1 Manual. Published online at: http://mrbayes.csit.fsu.edu/manual.php.

Rossman AY, Farr DF, Castlebury LA (2007) A review of the phylogeny and biology of the Diaporthales. Mycoscience 48:135-144

Rossman AY, Udayanga D, Castlebury LA, Hyde KD (2014) Proposal to conserve the name Diaporthe eres, with a conserved type, against all other competing names (Ascomycota, Diaporthales, Diaporthaceae). Taxon. accepted 
Salgado-Salazar C, Rossman AY, Chaverri P (2013) Not as ubiquitous as we thought: taxonomic crypsis, hidden diversity and cryptic speciation in the cosmopolitan fungus Thelonectria discophora (Nectriaceae, Hypocreales, Ascomycota). PLoS ONE 8(10): e76737. doi:10.1371/journal.pone.0076737

Salichos L, Rokas A (2013) Inferring ancient divergences requires genes with strong phylogenetic signals. Nature 497:327-331

Santos JM, Phillips AJL (2009) Resolving the complex of Diaporthe (Phomopsis) species occurring on Foeniculum vulgare in Portugal. Fungal Divers 34:111-125

Santos JM, Correia VG, Phillips AJL (2010) Primers for mating-type diagnosis in Diaporthe and Phomopsis: their use in teleomorph induction in vitro and biological species definition. Fungal Biol 114:255-270

Santos JM, Vrandečić K, Ćosić J, Duvnjak T, Phillips AJL (2011) Resolving the Diaporthe species occurring on soybean in Croatia. Persoonia 27:9-19

Schoch CL, Seifert KA, Huhndorf S, Robert V, Spouge JL et al (2012) Nuclear ribosomal internal transcribed spacer (ITS) region as a universal DNA barcode marker for Fungi. Proc Natl Acad Sci U S A 109:6241-6246

Schoch CL, Robbertse B, Robert V, Vu D, Cardinali G, Irinyi L, Kraichak E (2014) Finding needles in haystacks: linking scientific names, reference specimens and molecular data for Fungi. Database. doi:10. 1093/database/bau061

Sharma G, Kumar N, Weir BS, Hyde KD, Shenoy BD (2013) Apmat gene can resolve Colletotrichum species: a case study with Mangifera indica. Fungal Divers 61:117-138

Sieber TN (2007) Endophytic fungi in forest trees: are they mutualists? Fungal Biol Rev 21(2):75-89

Sieber TN, Dorworth CE (1994) An ecological study about assemblages of endophytic fungi in Acer macrophyllum in British Columbia: in search of candidate mycoherbicides. Can J Bot 72(10):1397-1402

Silva DN, Talhinas P, Várzea V, Cai L, Paulo OS, Batista D (2012a) Application of the Apn2/MAT locus to improve the systematics of the Colletotrichum gloeosporioides complex: an example from coffee (Coffea spp.) hosts. Mycologia 104: 396-409

Silva DN, Talhinhas P, Cai L, Manuel L, Gichuru EK, Loureiro A, Várzea V, Paulo OS, Batista D (2012b) Host-jump drives rapid and recent ecological speciation of the emergent fungal pathogen Colletotrichum kahawae. Mol Ecol 21:2655-2670

Sogonov MV, Castlebury LA, Rossman AY, Mejia LC, White JF (2008) Leaf-inhabiting genera of the Gnomoniaceae, Diaporthales. Stud Mycol 62:1-79

Stamatakis A (2006) RAxML-VI-HPC: maximum likelihood-based phylogenetic analyses with thousands of taxa and mixed models. Bioinformatics 22:2688-2690

Stamatakis A, Hoover P, Rougemont J (2008) A rapid bootstrap algorithm for the RAxML web servers. Syst Biol 57:758-771

Tamura K, Peterson D, Peterson N, Stecher G, Nei M, Kumar S (2011) MEGA5: molecular evolutionary genetics analysis using maximum likelihood, evolutionary distance, and maximum parsimony methods. Mol Biol Evol 28:2731-2739

Tan YP, Edwards J, Grice KRE, Shivas RG (2013) Molecular phylogenetic analysis reveals six new Diaporthe species from Australia. Fungal Divers 61:251-260
Taylor JW, Jacobson DJ, Kroken S, Kasuga T, Geiser DM, Hibbett DS, Fisher MC (2000) Phylogenetic species recognition and species concepts in fungi. Fungal Genet Biol 31:21-32

Taylor W, Turner E, Townsend JP, Dettman JR, Jacobson D (2006) Eukaryotic microbes, species recognition and the geographic limits of species: examples from the kingdom Fungi. Philos Trans R Soc Lond B Biol Sci 361:1947-1963

Thomidis T, Michailides TJ (2009) Studies on Diaporthe eres as a new pathogen of peach trees in Greece. Plant Dis 93:1293-1297

Toti L, Viret O, Horat G, Petrini O (1993) Detection of the endophyte Discula umbrinella in buds and twigs of Fagus sylvatica. Eur $\mathbf{J}$ Forest Pathol 23(3):147-152

Townsend JP (2007) Profiling phylogenetic informativeness. Syst Biol 56(2):222-231

Udayanga D, Liu X, McKenzie EHC, Chukeatirote E, Bahkali AHA, Hyde KD (2011) The genus Phomopsis: biology, applications, species concepts and names of common phytopathogens. Fungal Divers 50:189-225

Udayanga D, Liu XZ, Crous PW, McKenzie EHC, Chukeatirote E, Hyde KD (2012a) A multi-locus phylogenetic evaluation of Diaporthe (Phomopsis). Fungal Divers 56:157-171

Udayanga D, Liu XX, Crous PW, McKenzie EHC, Chukeatirote E, Hyde KD (2012b) Multilocus phylogeny of Diaporthe reveals three new cryptic species from Thailand. Cryptogamie Mycol 33:295-309

Udayanga D, Castlebury LA, Rossman A, Hyde KD (2014) Species limits in Diaporthe: a molecular reassessment of $D$. citri, D. cytosporella, D. foeniculina and D. rudis. Persoonia 32:83-101

Vajna L (2002) The role of Diaporthe eres in the early death of young fruit trees. Novenyvedelem Hungary 383(3):113-117

van Niekerk JM, Groenewald JZ, Farr DF, Fourie PH, Halleen F, Crous PW (2005) Reassessment of Phomopsis species on grapevine. Australas Plant Path 34:27-39

Voglmayr H, Rossman AY, Castlebury LA, Jaklitsch WM (2012) Multigene phylogeny and taxonomy of the genus Melanconiella (Diaporthales). Fungal Divers 57(1):1-44

Vrandečić K, Jurković D, Ćosić J (2010) Phomopsis vrste na vinovoj lozi $\mathrm{u}$ istočnoj hrvatskoj [phomopsis species on grapevine in eastern Croatia, in Croatian]. Glasilo biljne zaštite 4:246-252

Walker DM, Castlebury LA, Rossman AY, White JF (2012) New molecular markers for fungal phylogenetics: two genes for species level systematics in the Sordariomycetes (Ascomycota). Mol Phylogenet Evol 64:500-512

Walker DM, Castlebury LA, Rossman AY, Struwe L (2014) Host conservatism or host specialization? Patterns of fungal diversification are influenced by host plant specificity in Ophiognomonia (Gnomoniaceae: Diaporthales). Biol J Linn Soc 111:1-16

Watanabe M, Yonezawa T, Lee K, Kumagai S, Sugita-Konishi Y et al (2011) Molecular phylogeny of the higher and lower taxonomy of the Fusarium genus and differences in the evolutionary histories of multiple genes. BMC Evol Biol 11:322

Wehmeyer LE (1933) The genus Diaporthe Nitschke and its segregates. University of Michigan Press, Ann Arbor

Weir B, Johnston PR, Damm U (2012) The Colletotrichum gloeosporioides species complex. Stud Mycol 73:115-180

Wikee S, Lombard L, Crous PW, Nakashima C, Motohashi K, Chukeatirote E, Hyde KD (2013) Phyllosticta capitalensis, a widespread endophyte of plants. Fungal Divers 60:91-105 